\title{
The Utopian Internet, Computing, Communication, and Concrete Utopias: Reading William Morris, Peter Kropotkin, Ursula K. Le Guin, and P.M. in the Light of Digital Socialism
}

\author{
Christian Fuchs
}

University of Westminster, London, christian.fuchs@uti.at, http://fuchs.uti.at

\begin{abstract}
This paper asks: What can we learn from literary communist utopias for the creation and organisation of communicative and digital socialist society and a utopian Internet? To provide an answer to this question, the article discusses aspects of technology and communication in utopian-communist writings and reads these literary works in the light of questions concerning digital technologies and 21st-century communication. The selected authors have written some of the most influential literary communist utopias. The utopias presented by these authors are the focus of the reading presented in this paper: William Morris's (1890/1993) News from Nowhere, Peter Kropotkin's (1892/1995) The Conquest of Bread, Ursula K. Le Guin's (1974/2002) The Dispossessed, and P.M.'s (1983/2011; 2009; 2012) bolo'bolo and Kartoffeln und Computer (Potatoes and Computers). These works are the focus of the reading presented in this paper and are read in respect to three themes: general communism, technology and production, communication and culture. The paper recommends features of concrete utopian-communist stories that can inspire contemporary political imagination and socialist consciousness. The themes explored include the role of post-scarcity, decentralised computerised planning, wealth and luxury for all, beauty, creativity, education, democracy, the public sphere, everyday life, transportation, dirt, robots, automation, and communist means of communication (such as the "ansible") in digital communism. The paper develops a communist allocation algorithm needed in a communist economy for the allocation of goods based on the decentralised satisfaction of needs. Such needs-satisfaction does not require any market. It is argued that socialism/communism is not just a post-scarcity society but also a post-market and post-exchange society.
\end{abstract}

Keywords: communicative socialism, digital socialism, communist utopias, concrete utopia, utopian socialism, communism, communication studies, Marxist literary studies, Karl Marx, William Morris, News from Nowhere, Peter Kropotkin, The Conquest of Bread, Ursula K. Le Guin, the ansible, The Dispossessed, P.M., Hans Widmer, bolo'bolo, Kartoffeln und Computer, Potatoes and Computers, communist allocation algorithm

\section{Introduction}

This article discusses the following question: What can we learn from literary communist utopias for the creation and organisation of communicative and digital socialist society and a utopian Internet?

To provide an answer, the article discusses aspects of technology and communication in utopian-communist writings and reads these literary works in light of questions concerning digital technologies and 21 st-century communication. The selected writings include utopian outlines of a future communist society and communist novels. Due to limited space, a selection of important communist literary utopias had to be made. The selected authors have written some of the most influential literary communist utopias. The utopias presented by these authors are the focus of the reading presented in this paper: William Morris's (1890/1993) News from Nowhere, Peter Kropotkin's 
(1892/1995) The Conquest of Bread, Ursula K. Le Guin's The Dispossessed, and P.M.'s (1983/2011; 2009; 2012) bolo'bolo and Kartoffeln und Computer (Potatoes and Computers).

There are many other relevant books that could be included, but we have to leave it to other occasions to engage with further utopian-communist works. The present author also hopes to inspire other scholars to conduct comparable studies.

William Morris (1834-1896) was a British artist, activist and communist. He inspired the arts and crafts movement, founded the Socialist League, and played a major role in the League's newspaper The Commonweal. Morris's News from Nowhere is a utopian-communist novel that is set in a future communist society in the year 2102. Peter Kropotkin (1842-1921) was a Russian anarchist, scientist, writer, and activist. He is widely seen as the most influential theorist of anarcho-communism. Kropotkin's The Conquest of Bread outlines what a future anarcho-communist society could look like. Ursula K. Le Guin (1929-2018) was an American science fiction author. Her novels and short stories are often set in future anarcho-communist societies on distant planets. The Dispossessed is one of Le Guin's most widely read books. It describes life on the two planets Anarres and Urras. On the first planet, there is an anarcho-communist society. On the second planet, there are capitalist societies. P.M. is the pseudonym of the Swiss author Hans Widmer (born in 1947). Besides writing utopian novels, other literature, theatre performances, and radio plays, P.M. has also been an activist in autonomous and eco-socialist projects and movements. bolo'bolo is P.M.'s most wellknown book. Reminiscent of Kroptokin, bolo'bolo outlines how a future grassroots communist society without capital and the state could look. Kartoffeln und Computer ( $\mathrm{Po}$ tatoes and Computers) is an update of bolo'bolo's vision written almost thirty years later.

Raymond Williams (1978/2005) argues that utopian fiction often features the world altered by natural events, or by willed human transformations or technological transformations of society that result in or make visible aspects of paradise. Dystopian fiction has the same features, but they make visible aspects of hell. The article at hand focuses on utopian communist writings.

What is a utopia? What is utopian socialism? In the Manifesto of the Communist Party, Marx and Engels speak of critical-utopian socialism and communism as a kind of literature and a type of political movement in the late 17th and the early 18th centuries associated with Saint-Simon (1760-1825), Fourier (1772-1837), and Owen (17711851). Marx and Engels write that these authors' visions of communism and their social experiments took place in a period when "feudal society was being overthrown" and the "first direct attempts of the proletariat to attain its own ends" necessarily failed because of the "then undeveloped state of the proletariat" and "the absence of the economic conditions for its emancipation, conditions that had yet to be produced, and could be produced by the impending bourgeois epoch alone" $(1848,514)$. For Marx and Engels, these visions of a communist society came too early and could not be realised at the time they were conceived: "Such fantastic pictures of future society, painted at a time when the proletariat is still in a very undeveloped state and has but a fantastic conception of its own position, correspond with the first instinctive yearnings of that class for a general reconstruction of society" (1848, 515-516). Marx and Engels understand utopias as fantastic visions of future society that cannot be realised in a realistic manner under the current societal framework or in the near future. They criticise the abstract character of utopias; but they also state that "these Socialist and Communist publications contain also a critical element. They attack every principle of 
existing society. Hence, they are full of the most valuable materials for the enlightenment of the working class" $(1848,516)$.

In Socialism: Utopian and Scientific, Engels $(1880,290)$ writes that utopian socialists are "drifting off into pure phantasies". He argues that utopian socialism is moralistic and lacks a scientific analysis of capitalism and its contradictions: "The Socialism of earlier days certainly criticized the existing capitalistic mode of production and its consequences. But it could not explain them, and, therefore, could not get the mastery of them. It could only simply reject them as bad" $(1880,305)$. Engels thinks that Marx's works, Marx's approach of historical materialism, and the notion of surplus-value helped to turn socialism into a science:

These two great discoveries, the materialistic conception of history and the revelation of the secret of capitalistic production through surplus-value, we owe to Marx. With these discoveries Socialism became a science. [...] To accomplish this act of universal emancipation is the historical mission of the modern proletariat. To thoroughly comprehend the historical conditions and this the very nature of this act, to impart to the now oppressed proletarian class a full knowledge of the conditions and of the meaning of the momentous act it is called upon to accomplish, this is the task of the theoretical expression of the proletarian movement, scientific Socialism (Engels 1880, 305, 325).

Georg Lukács argues that although classical utopian-communist literature

[in its] step beyond Capitalism follows fantastic paths, its critical-historical basis is nonetheless linked - especially in the case of Fourier - with a devastating critique of the contradictions of bourgeois society. In Fourier, despite the fantastic nature of his ideas about Socialism and of the ways to Socialism, the picture of Capitalism is shown with such overwhelming clarity in all its contradiction that the idea of the transitory nature of this society appears tangibly and plastically before us $(1962,28)$.

The 20th century showed that science and technology and their class character have played a role in the advancement of exploitation, inequality, unemployment, precarity, environmental degradation, genocide, extermination, manipulation, etc. In addition, both social-democratic reformists, such as Bernstein, and Stalinists used the notion of scientific socialism for arguing that capitalism automatically collapses due to its internal contradictions, which behave like natural laws. They tried to transfer insights from the natural sciences to the social sciences, disregarding the differences between nature and society, and used naturalistic, deterministic and reductionist models of society for justifying pure reformism and state capitalist terror respectively. The natural science fetishism of revisionist social democracy and Stalinism has discounted and degraded the importance of class struggles. To speak of socialism as a science has become problematic, but the political perspective of socialism has remained highly important to this day.

Critical Marxist theories of technology make use of dialectical analysis in order to avoid the determinism inherent in revisionist and Stalinist theories. In light of the rise of authoritarian capitalism (Fuchs 2018; 2019), socialism needs not only brilliant analyses of what is wrong in society, but also visions of 21 st-century socialism that show how society can be transformed and what it can look like in the future in order to inspire contemporary class struggles. Perhaps contemporary socialist thought is sometimes too analytic. We need new inspirations from concrete-utopian socialism, from stories, 
visions, literature and popular culture, that tell us how socialism could work today and in the near future as communicative and digital socialism. Such stories can influence and inspire contemporary socialist strategies and class struggles.

Utopia is a word that has its origin in the combination of the two Greek words ou ('not') and topos ('place'). A utopia is a non-place, the place of nowhere. On the one hand, nowhere is a place that only exists in fantasy as dreams that will never be possible and therefore never come true. But on the other hand, utopias are also visions of society as a better place. Such socialist visions can become reality and inspire not just our dreams, but also our collective struggles for a better world.

Socialist science fiction writer Kim Stanley Robinson (2018a) argues that the difference between utopias and dystopias is that "utopias express our social hopes, dystopias our social fears". He argues that both utopias and dystopias often have an ideological character. Ideological dystopias tend to communicate that nothing can be changed and therefore to advance defeatism. Robinson therefore argues for the dialectical mediation of dystopias with socialist utopias:

These days I tend to think of dystopias as being fashionable, perhaps lazy, maybe even complacent, because one pleasure of reading them is cozying into the feeling that however bad our present moment is, it's nowhere near as bad as the ones these poor characters are suffering through. [...] utopia is the idea that the political order could be run better. Dystopia is the not, being the idea that the political order could get worse. Anti-utopias are the anti, saying that the idea of utopia itself is wrong and bad, and that any attempt to try to make things better is sure to wind up making things worse, creating an intended or unintended totalitarian state, or some other such political disaster. 1984 and Brave New World are frequently cited examples of these positions. [...] One way of being anti-anti-utopian is to be utopian. [...] An adequate life provided for all living beings is something the planet can still do; If dystopia helps to scare us into working harder on that project, which maybe it does, then fine: dystopia. But always in service to the main project, which is utopia" (2018a).

Robinson argues that utopias and science fiction tell us something about the time they were written in. They are manifestations of potentials, potential futures, hopes, and structures of feeling about society's reality at a certain time: "When you talk about the future you're always talking about history. A novel always does this, but science fiction does so explicitly, through thought experiments: 'If we do this we'll get here. If we do that we'll get there.' [...] science fiction is the realism of our time" (Robinson 2018b, 88). Science fiction is "describing the feel of our time. [...] It's not a factual analysis of the situation. It is not trying to predict the future. It is trying to say how this moment feels and what human history means right now" (Robinson 2017).

Ernst Bloch (1995) distinguishes in his book The Principle of Hope between abstract and concrete utopias. Abstract utopias outline impossible being. They remain stuck in "dreaminess" $(1995,146)$ and are "world-blind hope" $(1995,1039)$. Concrete utopias outline the not-yet of society, being that is possible but does not yet exist. They deal with "the Real-Possible" (146) and the "Not-Yet-Become-Good" (146). Concrete Utopias give grounds for "militant optimism" (146) and the "active hope" $(241 ; 1197)$ of class struggle. The "concretely utopian is an objective-real degree of reality on the Front of the occurring world, - as Not-Yet-Being" (205): "Concrete utopia stands on the horizon of every reality; real possibility surrounds the open dialectical tendencies and 
latencies to the very last" (223). In concrete communist utopias, the good life in communist society shines forth (Vorschein). The concrete communist utopia "is concerned to deliver the forms and contents which have already developed in the womb of present society. Utopia in this no longer abstract sense is thus the same as realistic anticipation of what is good; which must have become clear" (623). Concrete utopias aim at, as Marx writes, "making the world aware of its own consciousness, [...] awakening it out of its dream about itself", the "reform of consciousness not through dogmas", and making "evident that the world has long dreamed of possessing something of which it has only to be conscious in order to possess it in reality" $(1843,144)$.

The work at hand reads and interprets concrete utopian elements in the analysed communist writings in the light of the concrete potentials that the means of communication and digital technologies pose in the 21st century. Through an engagement with communist fiction it identifies elements of communicative and digital socialism that humans can collectively possess tomorrow if they manage to realise a socialist society through class struggles. My readings of Morris, Kropotkin, Le Guin, and P.M. uncover as-yet unrealised potentials of the contemporary means of communication that are real possibilities and give grounds for militant optimism and active hope for class struggles in and against digital capitalism that aim at the creation of communicative and digital socialism.

Section 2 focuses on Morris's News from Nowhere, Section 3 on Kropotkin's Conquest of Bread, Section 4 on Le Guin's The Dispossessed, and Section 5 on P.M.'s works bolo'bolo and Kartoffeln und Computer (Potatoes and Computers). Each of these sections contains three sub-sections discussing a) communism in general; b) technology and production in communism; and c) communication and culture in communism. Section 6 briefly introduces some other novels about post-scarcity communism. Section 7 draws some conclusions.

In the age of authoritarian capitalism, it is important that we dream about, imagine, talk about, envision, communicate, discuss, and struggle for concrete socialist utopias. In the 21st century, such socialist consciousness needs to pose the question of the digital in order to envision and realise concrete utopias. The proponents of neoliberal ideology and authoritarian capitalist ideology want to make us believe that there are no alternatives to capitalism and digital capitalism. It is precisely in this situation that it is of crucial importance, as Frederic Jameson (2005, xii) reminds us, that concrete utopian-communist thought recovers "its vitality as a political slogan and a politically energizing perspective" that advances "the dialectic of Identity and Difference" and inspire a politics that "aims at imagining, and sometimes even at realizing, a system radically different from this one".

\section{William Morris's News from Nowhere}

\subsection{Communism in General}

In Edward Bellamy's (1888/2007) novel Looking Backward: 2000-1887, Julian West falls asleep in the year 1887 and wakes up in a socialist United States in the year 2000. In this society, all industries are nationalised, humans retire at the age of 45 , citizens receive an equal share of goods and a credit of equal size provided on a debit card that is used for shopping, those performing unpleasant or dangerous labour work fewer hours than others, there is an industrial army performing compulsory labour in an efficient manner, education up to the age of 21 and the level of college is free, all types of labour are seen as being of equal importance, poverty and starvation do not exist, there is a low level of crime and disease, and there is free entertainment. 
Bellamy's novel was first published in 1888, which means that he could not envision computer technology, robots and a digitally automated economy, so that the economy he depicts is labour-intensive. Individuals retire early, but perform hard, highly disciplined labour as part of a compulsory labour service. The character Julian West comments: "[Y]ou have simply applied the principle of universal military service, as it was understood in our day, to the labor question" $(1888 / 2007,36)$. Dr Leete, who explains to West how American society works in 2000 , comments that labour is organised as "a disciplined army under one general" like "a fighting machine" (143). In this society, labour is toil and therefore alienated. High productivity is not achieved by the humanistic design and use of machines, but by the disciplining and military organisation of the workforce, which is an expression of inhumanity. In a foreword published in 1960, Erich Fromm commented on Looking Backward:

It is a society which not so much because of technical inventions, but rather through the rationality of its organization can produce enough to satisfy everyone's economic needs. [...] There is no effective democracy; only those over forty-five and not connected with the industrial army have the right to vote. The administration is organized according to the principles of an army. [...] it is nevertheless a society in which the majority of the citizens are subject to the commands of industrial officers, and have little chance to develop on their own initiative. [...] The aim of socialism was individuality, not uniformity; liberation from economic bonds, not the making of material aims into the main concern of life. Its principle was that each man is an end in himself, and must never be the means of another man (Fromm 1960).

Bellamy's fetishism of toil reminds us of Stalin, who wrote into the 1936 Constitution of the USSR: "In the U.S.S.R. work is a duty and a matter of honour for every able-bodied citizen, in accordance with the principle: 'He who does not work, neither shall he eat"' (USSR 1936, Article 12).

The British socialist writer, artist and activist William Morris reviewed Looking Backward. He wrote that

the impression which he [Bellamy] produces is that of a huge standing army, tightly drilled, compelled by some mysterious fate to unceasing anxiety for the production of wares to satisfy every caprice, however wasteful and absurd, that may cast up amongst them. [...] In short, a machine-life is the best which Mr Bellamy can imagine for us on all sides; it is not to be wondered at then that his only idea of making labour tolerable is to decrease the amount of it by means of fresh and ever fresh developments of machinery. [...] Now surely this ideal of the great reduction of the hours of labour by the mere means of machinery is a futility. The human race has always put forth about as much energy as it could in given conditions of climate and the like, though that energy has had to struggle against the natural laziness of mankind: and the development of man's resources, which has given him greater power over nature, has driven him also into fresh desires and fresh demands on nature, and thus made his expenditure of energy much what it was before. [...] I believe that the ideal of the future does not point to the lessening of men's energy by the reduction of labour to a minimum, but rather to the reduction of pain in labour to a minimum, so small that it will cease to be a pain; a gain to humanity which can only be dreamed of till men are even more completely equal than Mr Bellamy's utopia would allow them to be, but which will most assuredly come about when men are really equal in 
condition.[...] That variety of life is as much an aim of true communism as equality of condition, and that nothing but an union of these two will bring about real freedom (Morris 1889).

Based on his critique of Bellamy's novel, one year later Morris (1890/1993) published his own utopian communist novel News from Nowhere. Looking Backward started "the train of thought" that "led to his writing News from Nowhere" (Thompson 2011, 542). Frederic Jameson $(2005,144)$ argues that "Bellamy's industrial state (modeled on the army) is refuted by the anarchistic 'withering away' of the state in Morris, while the account of labor in Looking Backward (something like Marx's 'realm of necessity' opposed to the 'realm of freedom' of non-work and leisure time) is challenged by Morris's notion of a non-alienated labor which has become a form of aesthetic production". News from Nowhere is "not merely a contrasting utopia to Bellamy, it is a campaign against the whole mechanization of existence" (Bloch 1995, 613).

In News from Nowhere, the Victorian socialist William Guest wakes up and finds himself in a socialist society in the year 2102 . He wanders through this society and learns about it from Dick Hammond, Dick's great-grandfather, and others. In the end, it turns out that the visit to communism was a dream, but one that is a vision of a better society that can inspire humans in their struggles for a better world.

In the future socialist society William visits, there is no capital, no private property of the means of production, no exchange, no wage-labour, and no money. It is a classless society. There is no dull compulsion of the market forcing humans into wage-labour and class relations. They work voluntarily with the "freedom for every man to do what he can do best" (Morris 1890/1993, 123). Use-value shapes the economy, and humans produce for society's real needs, not for the accumulation of profit. The social environment and goods are beautifully designed so that beauty is a general principle of society. There is no poverty and all individuals are generally happy and beautifully dressed. There is gender equality. The overcoming of alienation and exploitation has enabled longevity and has drastically reduced crime, which has allowed the abolishment of prisons. A participatory democracy ("the whole people is our parliament" [107]) has replaced government, parliament, and the state. In News from Nowhere, there are separate houses for individuals and families, indicating that Morris considers privacy and individuality in a communist society to be important.

\subsection{Technology and Production in Communism}

In News from Nowhere, there is no compulsory labour. Everyone is very industrious, conducts self-chosen work that results in beautiful results, and is happy doing so. One of the depicted society's principles is "Thou shalt work in order to live happily" $(1890 / 1993,112)$. The novel features the work of weavers, housekeepers, "genuinely amusing work, like house-building and street-paving and gardening" (68), pot-making, glass-blowing, road-mending, hay-harvesting, or carving that workers experience as very pleasurable. For example, a road-mender working with a pick, says: "[it] is good work for hardening the muscles, and I like it; though I admit it is pleasanter the second week than the first" (83). And haymaking is presented as "easy-hard work" that "tries the muscles and hardens them" and "is always pleasant if you don't overdo it" (195).

One of the novel's basic assumptions is that making and creating something beautiful automatically makes workers happy. There is undoubtedly a certain truth to the claim that work that enables a high level of creativity can be self-fulfilling for humans. But not all work involves a high level of creativity, is pleasant, and creates beauty. Think for example of the cleaning of public toilets, the collection of garbage, and the 
inspection and cleaning of sewage ducts and sewage plants. Morris leaves open the question of how dirty work is conducted. In News from Nowhere, there is a certain idealisation of hard and mundane physical labour such as road-mending, street-paving, house-building, haymaking, or housework.

Morris $(1884,98)$ himself questioned that "all work is useful". He writes in the essay Useful Work Versus Useless Toil that it is an ideology to think "all labour is good in itself" $(1884,98)$. There is useless toil that is a curse and that humans should refuse (98). In this essay, Morris stresses the feasibility of the communist design and use of science and machines for automating and reducing toil:

Science duly applied would enable them [humans] to get rid of refuse, to minimize, if not wholly to destroy, all the inconveniences which at present attend the use of elaborate machinery, such as smoke, stench, and noise. [...] In a true society these miracles of ingenuity [labour-saving machines] would be for the first time used for minimizing the amount of time spent in unattractive labour, which by their means might be so reduced as to be but a very light burden on each individual. All the more as these machines would most certainly be very much improved when it was no longer a question as to whether their improvement would 'pay' the individual, but rather whether it would benefit the community (Morris 1884, 115, 117).

But in the same essay, there is also a passage that claims that certain forms of toil could be made pleasurable so that machinery could be replaced by human work: "So much for the ordinary use of machinery, which would probably, after a time, be somewhat restricted when men found out that there was no need for anxiety as to mere subsistence, and learned to take an interest and pleasure in handiwork which, done deliberately and thoughtfully, could be made more attractive than machine work" (Morris 1884, 117-118). Raymond Williams stresses that "Morris wanted the end of the capitalist system, and the institution of socialism, so that men could decide for themselves how their work should be arranged, and where machinery was appropriate" (Williams 1960, 167).

On the one hand, we find indications in News from Nowhere that science and technology are used in the way Morris pointed out in his essay Useful Work Versus Useless Toil. In the conversation between William Guest and old Hammond, the latter describes how the economy works in the communist society in the year 2102: "All work which would be irksome to do by hand is done by immensely improved machinery; and in all work which it is a pleasure to do by hand machinery is done without" (Morris $1890 / 1993,127)$. As a result, "allwork is now pleasurable" because it results in "honour and wealth" even if the "actual work is not pleasant", or work "has grown into a pleasurable habit", or "there is the conscious sensuous pleasure in the work itself; it is done, that is, by artists" (122-123).

Given that Morris wrote in the late 19th century, one cannot expect him to envision computing and robotics. His insight that communist science should develop and advance communist machinery that allows automating irksome and unattractive labour is an important principle of communism. Morris would agree that it is important that in a communist society there are robots that are capable of cleaning sewage and toilets.

In News from Nowhere, there is, however, also hard physical labour such as mundane housework, the mending of roads, the laying of bricks, and the harvesting of hay that he thinks can be made pleasurable in a communist society. In a communist soci- 
ety, there should not just be toilet- and sewage drain-cleaning robots, but highly efficient, ultra-fast washing machines available in every house or block of houses, dishwashers, robot vacuum cleaners, robot lawn mowers, robotic builders creating and mending roads and houses, agricultural robots, etc. Labour that is not itself pleasant should in a communist society be automated as far as possible. If someone enjoys hoovering floors, cleaning toilets, and washing dishes by hand, they will be able to do so and to volunteer to conduct such work not just for themselves but also for others. But a decisive aspect of a communist economy is that there are machines available that can conduct labour that is unattractive, irksome, annoying, or dangerous for humans.

In News from Nowhere, work is scarce (Morris 1890/1993, 81), but Morris does not give much attention towards describing the use of science and technology, although he makes clear that both are important in a communist society. There are factories without energy supply, where humans conduct hand-work (81). Roads are mended with picks (82-83). There was "the great change in the use of mechanical force" that led to the abolishment of manufacturing centres (102). In the story Morris tells, the revolutionaries have consciously decided to replace lots of activities carried out by machines by handicraft. Therefore, they speak of the end "of the machine period" that brought about "the transition from the makeshift work of machines [...] into the new handicraft period" (199-200). "[M]achine after machine was quietly dropped under the excuse that the machines could not produce works of art, and that works of art were more and more called for" (201). The communist society that William visits is "not an age of inventions" (192). Although it is not ruled out that machines are used for replacing unpleasant human labour, overall the society that Morris describes in News from Nowhere is a pre-industrial, agricultural socialism, where humans enjoy hard physical labour and beauty is the abundant result of handicraft.

It is reasonable to doubt that in a communist society many people find hard labour such as brick-laying, haymaking, road-mending, or street-paving pleasurable. Morris underestimates the humanistic potentials of modern technologies in communist society. It is a romantic idealisation to think that once private property and class relationships have disappeared, humans suddenly find joy in hard, exhaustive, monotonous physical labour.

What we can learn from Morris's utopian communist society is the importance of the principle of abundant beauty and the advancement of possibilities for creative work and work as art and play. Morris underestimates the potentials of modern technologies and could not envision a post-industrial socialism, where computing technologies and knowledge work play an important role and may enable the end of toil, unpleasant and dangerous labour and the maximisation of free, self-determined time used for leisure, creativity, social engagement, political debate, art, and human togetherness.

If it turns out in Morris's utopia that large groups of humans find physical labour cumbersome and unpleasant and stop doing it, and machines are not available for replacing them, then the economy could easily enter crisis, which could be a foundation of the return of a class society. A highly productive post-industrial socialism where robots and computing are used for providing possibilities to automate dangerous, unpleasant, stupefying, monotonous, and physical labour is less likely to return to a class society and more likely to provide happiness for all. Morris overestimated the interest and capacity of humans to find pleasure in mundane, hard physical labour. In a highly productive digital-communist society, humans can volunteer to conduct hard labour if they indeed find it pleasurable, but a decisive feature of such a society is that there are 
machines available that can to a significant degree conduct such work or make it less alienating.

\subsection{Communication and Culture in Communism}

In News from Nowhere, humans communicate with each other in a very polite manner. They are very friendly, open-minded, caring, and solidary. They call each other "neighbours". Here is an example from the book, where William in a shop receives a beautiful pipe and Latakia tobacco as gifts:

'I advise you to cram your bag, because you may be going where you can't get Latakia. Where is your bag?' I fumbled about, and at last pulled out my piece of cotton print which does duty with me for a tobacco pouch. But the girl looked at it with some disdain, and said: 'Dear neighbour, I can give you something much better than that cotton rag'. And she tripped up the shop and came back presently, and as she passed the boy whispered something in his ear, and he nodded and got up and went out. The girl held up in her finger and thumb a red morocco bag, gaily embroidered, and said, 'There, I have chosen one for you, and you are to have it: it is pretty, and will hold a lot' [...] 'Thank you so very much', I said at last, effusively, as I put the pipe in my pocket, not without a qualm of doubt as to whether I shouldn't find myself before a magistrate presently. 'Oh, you are so very welcome', said the little lass, with an affectation of grown-up manners at their best which was very quaint. 'It is such a pleasure to serve dear old gentlemen like you; specially when one can see at once that you have come from far over sea' (Morris 1890/1993, 73-74).

The political system that Morris depicts in News from Nowhere is a communicative participatory democracy (in Chapter IV): Citizens meet in neighbourhood assemblies, where they discuss matters of concern for the community. Suggestions for certain changes, such as building a new bridge or town hall, are made. If such proposals are supported by others, then pro- and counter-arguments are collected and published. In a later meeting, a "vote by show of hands" (119) is taken. If the minority is of significant size, then discussions and further votes continue until consensus is reached or the minority is happy to accept the decision.

Morris stresses that true democracy requires discussion and face-to-face assemblies. In the 21st century, Internet communication can support participatory democracy: The collection of arguments and counter-arguments can be started face-to-face, but can then be continued online. It can make use of user-generated content, wikis that allow the creation of collaboratively edited texts, videos that express the opinions of groups and individuals, links to and summaries of academic studies, online discussion, etc. Face-to-face communication can more easily create social cohesion than online communication, which is why in a participatory democracy digital communication should support, but not replace personal meetings and assemblies. Computer networks also enable electronic voting, which on the one hand allows increased participation, but on the other hand is susceptible to plebiscitary demagoguery, where the questions that are being asked and voted on are manipulative and defined by a minority.

In News from Nowhere, there are no telegraphs, telephones, or other two-way forms of mediated communication over distance. A call is made by blowing a buglehorn that attracts the attention of a particular person nearby (Morris 1890/1993, 51). People ride in horse-drawn carriages at a slow pace $(59-61 ; 62 ; 64 ; 164)$. William, Dick 
and Clara move from London to the countryside in a boat that sails on the Thames. The boats are rowboats powered by human sculling (202). In the society discussed by Morris, railways were abolished $(206 ; 215-216)$ and transport is based on human and animal power. There are no direct, two-way long-distance forms of communication. The organisation of transport and communication is toil. There are mysterious "force vehicles" that have "taken the place of our old steam-power carrying" (186), but it is not clear how they work, how important they are, and what exact role they play.

In capitalism, lots of long-distance transportation and communication has to do with the transport and marketing of commodities and the organisation of exploitation over distances. Transnational corporations can only exist based on global means of communication and transportation. Certainly, there would be less need for global transport in a communist society because commodities will have disappeared. But a communism that abolishes long-distance communication and transport deprives humans of the possibility to travel, learn about foreign cultures, and make friends all over the world. In such a society, culture is likely to be local and mundane. There would still be a need for transporting goods from one location to others where the conditions for the production of these use-values do not exist, in order to enable wealth for all. And there would still be the human need and desire to undertake travels to learn about the world, enjoy themselves, and meet others. There would no longer be travels for the organisation and management of exploitation. Fossil-fuel driven, individually owned cars would be unlikely to exist, but there would be effective networks of public transport. Fewer longdistance flights and journeys than today would be needed. Rockets, aeroplanes, buses, railways, trams, ships, cars, lorries, mopeds, cable cars, etc. will be solar-driven or powered by other forms of green energy. Those who enjoy driving buses or practicing the work of a captain of a ship or aeroplane would be able to do so. But there will also be the possibility to use highly developed, secure self-driving vehicles that utilise Artificial Intelligence.

In News from Nowhere, there is no formal school system; children learn practically and through curiosity (Chapter $\mathrm{V}$ ). They are highly educated and speak several languages. There is a certain hostility against books, reading, and writing, and children are not much encouraged to read $(68 ; 166 ; 175)$. There is a danger that in a society without books or with a lack of engagement with books individuals would lack imagination and society would become static, too pragmatic, and lack critical reflection capacities. Schools and formal education should continue to exist in a communist society, but there should be no performance principle and no grading system, and humans should be enabled to learn in a participatory manner.

\subsection{Conclusion}

We can learn from News from Nowhere that communism is likely to transform human culture, manners and behaviour so that humans are less aggressive and engage with each other in a much more friendly, open-minded, caring, and solidary manner than today. Beauty will not just be a feature of the natural and physical world, but also a characteristic of the human character and interpersonal relations.

The political system of a communist society requires the participation of humans in making decisions that concern their lives. Participatory democracy is the political system of a communist society. In such a society, there is enough motivation, interest and time available for humans to engage in political debates and decision-making. Computer networks will support democratic information and communication; not replacing, but rather enhancing face-to-face assemblies and debates. 
In a communist society transport and communication should not entail toil and localism as in News from Nowhere, but, based on green computing and green transport technologies, should enable humans to communicate and travel globally so that they learn from each other, enjoy discovering the world and meeting other people in distant cultures, and create a global community of friends. In a communist society, schools would continue to exist but be organised as participatory organisations. Learning, reading, writing, art, critical thinking, critical arguing, critical reading, critical writing and critical debating would be encouraged and practiced in cultural communities of life-long learners and cultural creators. Digital technologies would be used for supporting these critical and cultural skills.

\section{Peter Kropotkin's The Conquest of Bread}

\subsection{Communism in General}

Peter Kropotkin was a leading anarcho-communist thinker and activist. In his book The Conquest of Bread, Kropotkin (1892/1995) outlines the utopia of an anarcho-communist society and explains how the economic, political and cultural foundations of such a society can be organised.

Kropotkin's communism is based on the collective ownership of the means of production enabling wealth for all and luxury for all. The economy is built on the principle of mutual aid. Companies are worker-controlled and houses owned by those who live in them: "The common possession of the instruments of labour must necessarily bring with it the enjoyment in common of the fruits of common labour" (1892/1995, 32). Communist anarchism is based on the principle "to every man according to his needs" (33). There is no wage-labour, no money, and no exchange, but distribution of goods according to needs in the form of gifts. Humans themselves know best what they need. Communism uses the principle "[t]ake what you need" (34). Kropotkin is influenced by Marx $(1875,87)$, who formulated the principle "[f]rom each according to his abilities, to each according to his needs" as one of the cornerstones of a communist society. Kropotkin argues that in communism the state and governments should be replaced by free agreements between communes; that there is no need for authority in order to make organisation work.

Murray Bookchin further developed Kropotkin's approach into libertarian municipalism. The municipality is an important organisational unit. There are also confederations of municipalities, i.e. communes of communes:

the 'apex' of all authority would lie with the municipal assemblies, guided by majority rule both in the assembly and among the assemblies of a confederal region; the 'base' would lie with the broadest confederal councils whose work is simply administrative and adjudicatory, and whose deputies, drawn from smaller confederal bodies, would be easily recallable and subject to careful popular oversight (Bookchin 1992, xix-xx).

Confederalism takes on the form of a "commune of communes" (1992, xxi), to which municipalities send delegates that debate matters concerning citizens at levels of organisation above the municipality. Participatory democracy requires "personal interaction" and "face-to-face education" fostering "the development of a face-to-face democracy" (xxiv). We can add to Bookchin's view that in the age of the Internet, certain preparatory contributions and information can also be provided online so that online 
information, online communication, and user-generated online content support faceto-face deliberation and decision-making.

\subsection{Technology and Production in Communism}

For Kropotkin, communism is a highly productive, post-scarcity society that makes use of and further develops the means of production:

It now remains for society, first, to extend this greater productivity, which is limited to certain industries, and to apply it to the general good. But it is evident that to utilize this high productivity of labour, so as to guarantee well-being to all, Society must itself take possession of all means of production. [...] It is a case of producing the greatest amount of goods necessary to the well-being of all, with the least possible waste of human energy $(1892 / 1995,88,89)$.

In the 21st century, communism can make use of digital technologies in order to increase productivity and create wealth and luxury for all beyond scarcity and necessity. Kropotkin reminds us that communism requires technological foundations and that communism today requires digital foundations.

Further developing Kropotkin's communist anarchism, Murray Bookchin (1986) argues for the use of computing technologies as liberatory technologies that form one of the foundations of a post-scarcity society. A post-scarcity society realises what Kropotkin terms wealth for all and luxury for all:

Post-scarcity society, in short, is the fulfillment of the social and cultural potentialities latent in a technology of abundance. [...] a new technology has developed that could largely replace the realm of necessity by the realm of freedom. [...] It is arguable whether computer 'intelligence' is, or ever will be, creative or innovative (although every few years bring sweeping changes in computer technology), but there is no doubt that the digital computer is capable of taking over all the onerous and distinctly uncreative mental tasks of man in industry, science, engineering, information retrieval and transportation. Modern man, in effect, has produced an electronic 'mind' for coordinating, building and evaluating most of his routine industrial operations (Bookchin 1986, 13, 115, 123).

Comparable to Bookchin, Herbert Marcuse also developed a concept of liberatory technology. For Marcuse, a true society "presupposes freedom from toil" $(1964,133)$ and therefore requires highly productive technologies designed and applied in humane and sustainable ways. He defines the "good life" as "a life which is as much as possible free from toil, dependence, and ugliness" $(1964,130)$. A communist society needs "the planned utilization of resources for the satisfaction of vital needs with a minimum of toil, the transformation of leisure into free time, the pacification of the struggle of existence" (257).

In communism, modern technologies are not abolished, but radically reconstructed:

If the completion of the technological project involves a break with the prevailing technological rationality, the break in turn depends on the continued existence of the technical base itself. For it is this base which has rendered possible the satisfaction of needs and the reduction of toil - it remains the very base of all forms of human freedom" (Marcuse 1964, 236).

Capitalist technology has to be sublated and a technology of liberation to be created: 
For freedom indeed depends largely on technical progress, on the advancement of science. But this fact easily obscures the essential precondition: in order to become vehicles of freedom, science and technology would have to change their present direction and goals; they would have to be reconstructed in accord with a new sensibility - the demands of the life instincts. Then one could speak of a technology of liberation, product of a scientific imagination free to project and design the forms of a human universe without exploitation and toil" (Marcuse 1969, 19).

In 19th-century socialism, communists such as Marx and Engels argued that the abolition of the state, exchange, and wage-labour was not immediately possible and that therefore an intermediate stage between capitalism and communism was needed, where the state continues to exist and co-ordinates production. Anarchists such as Bakunin and Kropotkin argued, in contrast, that the state needed to be immediately abolished together with capital and that the immediate creation of a society without domination was possible and necessary. Whereas Marxists favoured a combination of revolutionary and parliamentary politics in order to seize state power, anarchists argued against party politics. The conflict between the communists around Marx and the anarchists around Bakunin led to the split of the First International in 1872.

Marx's criticism of anarchism was certainly correct in the 19th century: even in the most developed countries, productive forces were not developed to a degree that would have allowed the immediate transition to a fully communist society. In the 19th century, anarchists had a naïve, idealist, abstract-utopian image of post-capitalism. In the age of digital capitalism, the levels of productivity are so high that the first stage of communism is no longer needed and a widely advanced communism that enables post-scarcity and wealth for all could be immediately introduced. In the age of digital technology, the traditional conflict between Marxist communists and communist anarchists about the question of whether an interim stage is needed between capitalism and full communism has become superfluous.

Kropotkin argues that the principle of "Bread for All" and assuring the provision of "Shelter, food, and clothes to all" (1892/1995, 55, emphasis in original) is the most immediate need in the course of and after a revolutionary transition to a new society. But he also points out that beyond the satisfaction of these very basic needs a communist society needs to be able to guarantee not only the physical survival of its inhabitants, but also the need of luxury for all: "After bread has been secured, leisure is the supreme aim" (95). Kropotkin follows Marx's insight that communism and the communist application of technology enable the "wealth for all" and that free time "will grow for all". In a communist society, the "measure of wealth is then not any longer, in any way, labour time, but rather disposable time" (Marx 1857/1858, 708). In 21st-century society, wealth for all also includes the access of all to the world's knowledge as knowledge and digital commons and the gratis access of all to creative and digital skills and the cultural resources needed for universal artistic and creative production so that everyone can become artistically and an intellectually accomplished.

Kropotkin argues that as a result of technological developments in communism, humans will engage in diverse free activities "to satisfy [...] artistic or scientific needs" and have ample time available for their hobbies (1892/1995, 97). The social revolution opens up universities, laboratories, research institutes and science to all and thereby promotes "the spirit of invention" and the "impulse to thought, this boldness, this knowledge, this conviction of working for all" $(1892 / 1995,102)$, which in turn helps to advance society's productive forces and the development of knowledge, science, and 
technology. A revolution "implies the awakening of human intelligence, the increasing of the inventive spirit tenfold, a hundredfold, it is the dawn of a new science" (177). Based on William Morris, Kropotkin argues that in a communist society that maximises free time, work becomes art (105) and everyone can become an artist.

Kropotkin stresses that a communist society must use and develop the means of production and employ certain forms of collective reproductive labour (e.g. the provision of services such as public kitchens providing free food or the collective washing services of clothes and dishes) in order to rid itself of hard, dangerous and unpleasant labour:

Cleaning, rubbing the skin off your hands when washing and wringing linen; sweeping floors and brushing carpets, thereby raising clouds of dust which afterwards occasion much trouble to dislodge from the places where they have settled down, all this work is still done because woman remains a slave, but it tends to disappear as it can be infinitely better done by machinery. Machines of all kinds will be introduced into households, and the distribution of motor-power in private houses will enable people to work them without muscular effort. [...] But emancipation from domestic toil will not be brought about by small machines only. Households are emerging from their present state of isolation; they begin to associate with other households to do in common what they did separately" (Kropotkin 1892/1995, 112).

Future communism requires digital machines such as toilet-cleaning robots, robotic waste collection and recycling, robot vacuum cleaners, robot lawn mowers, robot builders, agricultural robots, etc. in order to automate as widely as possible dangerous, exhausting, monotonous, mundane, boring, and unpleasant necessary labour. This excludes certain work such as human care because robotic psycho-therapists and carers are inhumane and would make people more ill and unhappier instead of supporting them. Robots can be used in meaningful ways in medicine, for example in robot-assisted surgery, where the robot supports but does not replace the human surgeon. In care, labour such as moving hospital beds, changing sheets, cleaning instruments, washing the laundry, etc. can certainly be automated and robotised without fostering inhumanity.

In the book Four Futures: Life After Capitalism. Peter Frase $(2016,47)$ argues that in a communist society, robots should conduct "the more emotionally complex aspects of care" and writes that "a robot nurse could be more comforting than an overworked and exasperated human one" $(2016,47)$. In a communist society, those who need care will not automatically be put into special institutions, but will to a larger degree than today live with their family and friends. On the one hand, more time would be available for friends and family to undertake care work. And on the other hand, there will still be professional carers who practice care out of communist solidarity. In a communist society, where humans are solidary, more humans will be interested in engaging for a certain number of hours per year in professional care work. Robotic emotional care does not work and is inhumane because machines do not have and cannot properly simulate feelings, ethics, and emotions. Robotic psychotherapists, doctors, nurses, midwives, etc. are not an expression of communist care, but of inhumane, alienated care.

Kropotkin argues for the creation of agro-industrial communes, which can be achieved by creating urban fields and agricultural parks so that land, food and industry are organised close by one another: 
If fields are to be properly cultivated, if they are to yield the abundant harvests that man has the right to expect, it is essential that workshops, foundries, and factories develop within the reach of the fields. A variety of occupations, and a variety of skill arising therefrom, both working together for a common aim these are the true forces of progress (Kropotkin 1892/1995, 175).

Today, we need communist agro-industrial-digital communes, where tangible and intangible production are organised in the same locales and the division between mental and manual work can more easily be overcome than in an international division of labour. In a digital communist society, digital technologies will advance the digital support of agriculture, manufacturing and services so that the division of labour can be abolished, necessary labour can be minimised, and free work beyond necessity and compulsion can be maximised.

Given that the computer is a universal machine, in a communist society it can be used as a tool that supports the sublation of the division of labour; the divisions between agriculture, industry and services, producers and consumers, mental and manual labour, town and countryside, developed and developing countries, productive and reproductive labour, paid and unpaid labour, the international division of labour, the gender division of labour, and so on. For example, the digitisation of agriculture, manufacturing and services makes it easier to organise these forms of production in all localities so that the distinction between the rural countryside, the post-industrial global metropolis, and de-industralised cities becomes superfluous.

In a communist society, a diversity of realms of production could flourish independent of location and the division of labour could, along with class society, be abolished. But not everything can be produced everywhere. You cannot grow bananas in Scandinavian gardens. There will always remain a certain need for international mutual aid and international gifting co-ordinated via networked computer systems that record the global demand for goods as well as the production capacities in self-managed companies, communes, communes of communes, regions, etc.

\subsection{Communication and Culture in Communism}

Communist society will possess the material foundation and productivity that allows the sublation of the division of labour between mental and manual labour:

It is precisely to put an end to this separation between manual and brain work that we want to abolish wagedom, that we want the Social Revolution. Then work will no longer appear a curse of fate: it will become what it should be - the free exercise of all the faculties of man (Kropotkin 1892/1995, 133).

Kropotkin follows Marx's concept of the well-rounded individual that emerges based on communism's abolition of the division of labour. Marx speaks of a

communist society, where nobody has one exclusive sphere of activity but each can become accomplished in any branch he wishes, society regulates the general production and thus makes it possible for me to do one thing today and another tomorrow, to hunt in the morning, fish in the afternoon, rear cattle in the evening, criticise after dinner, just as I have a mind, without ever becoming hunter, fisherman, shepherd or critic" (Marx and Engels 1845/1846, 47).

In digital communism, it is possible that the well-rounded individual creates digital videos in the morning, cooks a meal whose recipe they have obtained from a friend over 
the Internet in a collective kitchen at noon, spends time with family and friends in the afternoon, prepares themselves via the Internet for the next day's local assembly where an important collective decision will be taken in the early evening, then together with others cooks a meal, and in the evening continues the work on a novel that will be distributed online and as a free paperback using a Creative Commons licence.

Kroptokin argues for creating a different kind of school system that works without authority, the performance principle, and grading:

the child reputed lazy at school is often the one which simply does not understand, because he is being badly taught. [...] Do not you see that by your methods of teaching, framed by a Ministry for eight million scholars, who represent eight million different capacities, you only impose a system good for mediocrities, conceived by an average of mediocrities? Your school becomes a University of laziness, as your prison is a University of crime. Make the school free, abolish your University grades, appeal to the volunteers of teaching; begin that way, instead of making laws against laziness which only serve to increase it (1892/1995, 141, 142-143).

\subsection{Conclusion}

In the digital age, Kroptokin's vision of a communist society remains highly relevant. Although in the 19th century computing could not be envisioned, Kropotkin was, like Marx, an anticipatory thinker, who saw communism as a highly productive society, where technologies are designed in humanistic ways and support the creation of wealth and luxury for all.

In the 21st century, communism can make use of digital technologies in order to increase productivity and create wealth and luxury for all beyond scarcity and necessity. Kropotkin reminds us that communism requires technological foundations.

\section{Ursula K. Le Guin's The Dispossessed}

\subsection{Communism in General}

Ursula K. Le Guin's (1974/2002) The Dispossessed is a science fiction novel that deals with life in future societies located on two different planets: the communist planet Anarres and the capitalist society A-lo on the planet Urras. In the 1960s and 1970s, there was "a whole explosive renewal of Utopian thinking and imagination, and for a rebirth of the older narrative form. Ursula K. LeGuin's The Dispossessed [...] was the richest literary reinvention of the genre" (Jameson 1991, 160).

On Urras, societies are shaped by private property, classes, capital accumulation, money, and commodity exchange on markets. The reader learns that on this planet and in its various national societies, one finds commodity fetishism, a gender division of labour, competition, tabloid journalism, exams in universities and schools, and wars. It is a generally rich, but unequal, exploitative and war-waging planet. Visiting Urras from Anarress, the book's main protagonist Shevek comments: "And you the possessors are possessed. You are all in jail. Each alone, solitary, with a heap of what he owns" (1974/2002, 190).

On Anarres, we find collective worker ownership of companies and their means of production (syndicates), federations of organisations, participatory democracy, gender equality, and an administration (Production and Distribution Coordination, PDC) that does not rule over citizens but merely coordinates production. PDC consists of volunteers who are selected by lot and serve for a period of five years $(1974 / 2002,14)$. 
There are no contagious diseases on Anarres. Anarres is built on mutual aid and solidarity, its principles are "to give, not to sell" (15) and "[h]aving's wrong, sharing's right" (44). We learn that people typically work five to seven hours a day and four to five and a half days a week (156), which means between twenty and thirty-eight hours and a half per week.

The settlers who built society on Anarres deliberately left Urras because they wanted to escape from capitalism. On Anarres, they built an alternative society, the Odonian society. But Anarres is a planet with low vegetation, rough climate and no animals: "Anarres is all dust and dry hills" (189). It is much more difficult to sustain an economy there than on Urras. The advantage of these conditions is that it is unlikely that imperialists from Urras try to conquer Anarres because there is no wealth to be exploited. They will stick to organising exploitation on their own planet. But the disadvantage is that building a communist society under such difficult environmental conditions is hard; almost impossible. The result is that Anarres is a rather poor socialist society with low productivity that experiences phases of collective hardship, poverty, famine, and drought. Scarcity is also a potential source of the emergence of class divisions: Anarres faces the danger of turning into a class society.

Anarres is not free of antagonisms and asymmetric power. The book discusses the case of the scientist Sabul who uses his reputation and influence to make others work for him and take the credit for their labour, a process that can be termed academic exploitation.

\subsection{Technology and Production in Communism}

Heavy physical, unpleasant, or dangerous labour exists on Anarres and is organised as labour performed on rotational duty. Labour such as toilet cleaning and waste collection is collectivised. Shevek explains: "Well, we all do them. But nobody has to do them for very long, unless he likes the work. One day in each decad [= ten days] the community management committee or the block committee or whoever needs him can ask him to join in such work. [...] People take the dangerous, hard jobs because they take pride in doing them, they can - egoise, we call it - show off" $(1974 / 2002,124$ 125).

In The Dispossessed, adverse economic and environmental conditions result in a four-year long period of famine. Individuals take on jobs wherever they are needed, which rips apart families and friendships and makes people unhappy. There is no forced labour. Individuals could refuse accepting jobs in regions away from their friends and family. But their sense of duty and a culture where the collective interest is seen as much more important than the individual interest makes them reject this option, as they do not want to be seen as individualists: "To survive, to make a go of life, an Anarresti knew he had to be ready to go where he was needed and do the work that needed doing" (204).

The book shows that a socialism of scarcity is built on the principle of equality, but does not automatically make individuals and society happy and renders it difficult to realise a dialectic of collective and individual interests. Whereas capitalism fetishizes individualism without nourishing the collective and common good, the socialism of scarcity fetishizes collectivism without individuality and does not give enough space to individual interests and needs. High productivity is a necessary, but not sufficient condition for a socialism that enables wealth and happiness for all. The Dispossessed presents, as the subtitle of some editions of the book indicates, an "ambiguous utopia". Carl Freedman $(2000,122)$ argues that The Dispossessed is "a self-critique of anarchism" because it shows that "material privation not only sets quantitative limits to the 
achievements of socialism; it may qualitatively deform socialist values at their very core".

In contrast to the situation on Anarres, labour on Urras is highly productive and creates an overall richer society. Visiting Urras, the book's main protagonist Shevek is impressed by "the greatness of the enterprise" of building space ships on Urras, whereas the ships of Anarres' space fleet are two hundred years old. To "build just a ship to carry grain across the sea [...] it takes a year's planning, a big effort of our economy" (1974/2002, 73). Le Guin's book risks the danger of cementing the myth that a communist society is necessarily less productive and poorer than a capitalist society.

Frederic Jameson $(2005,159)$ argues that Le Guin's novels are

the prototype of a Utopian commitment to the countryside and the village, to agriculture and small face-to-face groups, as opposed to the urban celebrations of a Delany: the commitment of a pastoral Morris, as opposed to the industrial Bellamy. Indeed, the opposition probably becomes meaningful only after industrialization in the nineteenth and twentieth centuries".

On the one hand, there is validity in the criticism that Le Guin omitted description of high-tech communism. Reynolds $(2005,87-88)$ argues that "Le Guin's suggestion is that, so long as $[\ldots]$ suffering is freely shared like everything else, then even the most extreme hardship may be chosen and made part of one's freedom". On the other hand, in response to the criticism that her novels avoid high-tech Le Guin writes that technologies such as making a fire without matches are very complex and that "all science fiction is, in one way or another, technological." She says that in her novels, the "hard stuff's inside, hidden" (2004). There are computers on Anarres and in an anarchoprimitivist society without science and technology, a tech-communist such as Shevek simply would not exist.

Le Guin does not provide the answers to how high-tech communism is possible, but she inspires us to ask the right questions, such as: What would have happened if the settlers had stayed on Urras and had successfully organised a revolution? What would a communist society look like on Urras? Such questions are the "hard stuff" that is hidden inside her novels. In this context, Hamner $(2005,228)$ argues that The Dispossessed is "an incomplete utopia, but we see the beginnings of revolution in Thu and A-lo and the hope of renewed progress in the revolution on Anarres".

When Shevek visits Urras, his hosts try to keep him from meeting the poor because they are afraid he could lead or inspire such a revolution. The dominant class on Urras is interested in Shevek's theory of simultaneity and tries to hide him from the propertyless class. The real concrete utopian-communist potential that the book outlines occurs when Shevek joins revolutionaries in Benbili, an undeveloped part of Urras, where the propertyless rebel against their exploitation. This part of the story focuses on class struggle as the potential for the creation of a highly developed communist society. The settlers have fled not just from capitalism, but also from class struggle. They were abstract utopians trying to create an autonomous communist society under improper material conditions.

On Anarres, there are computers that co-ordinate "the administration of things" (Le Guin 1974/2002, 82). The Division of Labour Office (DivLab) hosts a huge database that contains information about every job that needs to be done, the priorities of all workers, and their assignments (1974/2002, 222). Le Guin hints at the importance of co-ordinating the demand and supply of labour in a communist society via networked computing. 


\subsection{Communication and Culture in Communism}

There are no national languages on Anarres. People speak Pravic, which like Esperanto is a constructed language. On Anarres, there is not so much need for long-distance communication via radio, telephone, and postal mail because there is no sales communication (Le Guin 1974/2002, 208). There is little sense of privacy on Anarres, which is why personal letters are not sealed (1974/2002, 209). Life is very local, and personal telephone calls are rare and have to be arranged in advance (209). The PDC controls which letters are sent to Urras or rejected, because the latter's inhabitants are seen as enemies (133): there is censorship of such communication.

Shevek is a real communist. He creates his theory of time because it can underpin the creation of an instantaneous, interstellar communication system, an Internet of the Universe that is called the "ansible", which is short for "the answerable". The ansible is "a device which will permit communication without any time interval between two points in space. [...] So we will be able to use it to talk between worlds, without the long waiting for the message to go and the reply to return. [...] Like a kind of telephone" (283). Like Tim Berners-Lee, who made the World Wide Web a commons, Shevek does not want to earn money from his theory and the resulting communication system, but wants to give his ideas to the world as a gift. Shevek explains his motivation: "I'd like to share it out. [...] It ought to be given out, handed around. It won't run out!" (311). The Dispossessed is the story of how Shevek invents the ansible, which exists as interstellar Internet in the ten books that make up Le Guin's "Hainish Cycle".

Le Guin (1966) had already introduced the ansible in her first novel Rocannon's World, where it is spoken of as "the big machine [...] which can speak instantly to other worlds, with no loss of years". In The Left Hand of Darkness, Le Guin (1969/2017) describes the "ansible communicator" as working on the "constant of simultaneity", requiring no radio waves and producing "a message at any two points simultaneously". "A NAFAL ship takes 67 years to go between Gethen and Hain, but if I write a message on that keyboard it will be received on Hain at the same moment as I write it" (1969/2017). The Dispossessed reveals the origin of the ansible in Shevek's development of a General Temporal Theory.

Raymond Williams (1978/2005) argues that in science fiction, utopian transformations are all too often not "social and moral but natural". Le Guin's The Dispossessed deprives "utopia of its classical end of struggle" (1978/2005, 212) by an "open utopia" (211) where "the good land is in the grip of the Urrasti dominance" (211). Shevek is the social character typifying the struggle for the open communist utopia.

Comparable to Jürgen Habermas, Shevek believes in the good potentials of communication. He says that "[s]peech is sharing - a co-operative art" (Le Guin 1974/2002, 28 ) and sees communication as a means "to unbuild walls" (1974/2002, 65). For Shevek, communication is an important foundation of universal peace, peace in the Universe. Shevek describes the potentials of the ansible as "making a league of worlds possible. A federation" (284). He imagines the creation of an interstellar public sphere that fosters peace and understanding.

But the example of the Internet commons shows that in a world that has not rid itself of class divisions, dominant classes can turn the commons into commons of capital and commons of authoritarianism. Created as a commons, the World Wide Web is today dominated by the likes of Alphabet/Google, Amazon, Facebook, and Alibaba. In 
2019 , these four companies together made profits of over US $\$ 70$ billion from the commodification of the Internet ${ }^{1}$. And there is also the political colonisation of the Internet by authoritarians. Using Twitter, Donald Trump communicates in order to build physical and political walls (see Figure 1).

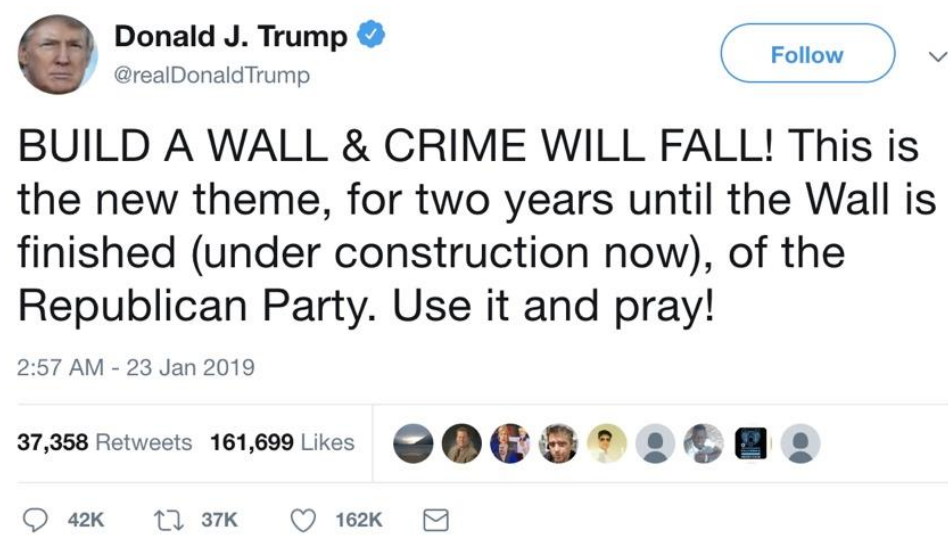

Figure 1: Tweet by Donald Trump, source: http://www.twitter.com, accessed July 15, 2019

Communication is neither good or evil by nature; it is a tool mediating good and evil social relations. Habermas (1991) points out that there are economic and political forms of the colonisation and feudalisation of the public sphere. Commodification and authoritarianism have colonised the Internet.

We can learn from Le Guin's works that universal and global communication systems need to rid themselves of commodification and authoritarianism and be designed and used in a participatory-democratic manner in order to foster the public sphere, peace, and global understanding. A communist society needs a communist system of communication that is based on the principles of common access, common use, and the creation of possibilities for common encounters of humans that strengthen solidarity and friendship.

\subsection{Conclusion}

Ursula Le Guin's The Dispossessed does not convince as a utopian story of what a communist society could look like. Anarres is a failed experiment where power inequalities cannot be overcome and humans suffer and are unhappy under the conditions of a socialism of scarcity. The book's strength is the portrayal of Shevek as a communist social character who is both opposed to capitalism on Urras and the unhappy life on Anarres. He is a tech-communist who makes his invention, an interstellar Internet of the Universe, available as a common good and sees the communist potentials of technologies for the creation of a truly humanist and communist world. Socialist transformation requires many Sheveks.

${ }^{1}$ Data source: Forbes 2000 List of the World's Largest 2,000 Companies for the year 2019, https://www.forbes.com/global2000/list/, accessed on 18 July 2019. 


\section{P.M.'s bolo'bolo}

\subsection{Communism in General}

P.M. (1983/2011) outlines in his utopian work bolo'bolo the foundations of a society that is free from domination, capitalism, and the state.

"bolo'bolo" is a society of autonomous communities. A bolo is a "large communistic" household $(1983 / 2011,20)$ consisting of 300 to 1,000 individuals. Bolos are spaces of communication, production, and reproduction. A bolo is a "direct, personal context for living, producing, dying" (72-73). P.M. thinks that a community of 500 individuals constitutes the ideal size of a bolo (22-23). As far as possible, a bolo tries to organise food production locally so that it is "largely self-sufficient so far as the daily supply of basic food is concerned" (75). The introduction of urban farming is common in a bolo. The basic necessities of life are provided for free to the members of a bolo.

P.M. argues that necessary work guaranteeing survival (such as agricultural work) must be compulsory and divided among all members. Typically, it would constitute 10 percent of the available active time $(88 ; 119)$. P.M. suggests that 10 percent of the working time in a bolo could be passed over to the township so that production for trans-local needs could be organised (119). The township could pass over 10 percent of the total working time it contains to the region, which again could pass over 10 percent to the planetary community (119). "Organising more complex forms of production - "water, energy, raw materials, transportation, high tech, medicine, etc." (97) - requires "exchange and co-operation" across bolos "on higher social levels: towns, valleys, cities, regions, continents - for raw materials, even world-wide" (97).

P.M. suggests that ten to twenty bolos together form townships (120) organising common institutions (such as hospitals), and that counties consist of ten to twenty townships (124-125). Autonomous regions are made up of twenty to thirty counties (126). Based on P.M.'s assumption that an ideal bolo has 500 members, a county bears a maximum of 200,000 inhabitants and a region a maximum population of 6 million. According to P.M., the Earth could consist of "about 700 regions in all" (130), which means a maximum of 4.2 billion inhabitants. In 2020 , the world population was 7.8 billion; in 1983, the year bolo'bolo was first published, it amounted to 4.7 billion².

Forcibly reducing the world population is not compatible with a free society. It is in this context a bit disturbing that P.M. suggests that every individual should be equipped with a suicide/death pill $(79 ; 111-112)$, that medieval duels should be revived $(79 ; 147-$ $149)$, and that "longevity won't be a general value" (110). But in his work Kartoffeln und Computer (Potatoes and Computers), it becomes evident that P.M. (2012, 20; 43; $2009,17 ; 19)$ in no way supports repressive population policies and revises his vision so that there are enough organisational units that are the homes of 9 billion individuals. In Kartoffeln und Computer, P.M. identifies more organisational units than in bolo'bolo: neighbourhoods, boroughs/towns, cities, territories, (sub-)continents, the planet (2009, 19).

The idea of population reduction has been part of the reactionary and racist politics of Social Darwinism. An anarchist version of such politics needs to be avoided. A long, healthy and happy life for everyone is desirable and only becomes possible in a communist society that does not deny but supports medical progress for all. At the global level, the average life expectancy of those born in 2020 is 73.2 years and, of those that will be born in $2100,81.7$ years $^{3}$. Such progress should be celebrated, not denied in a

${ }^{2}$ Data source: UN Population Statistics, https://population.un.org

${ }^{3}$ Data source: UN Population Statistics, https://population.un.org 
necrophilic manner akin to fascination with death. If possible and enabled by scientific progress, then all individuals in the world should enjoy a good, long life.

P.M. suggests that large cities should be "thinned out" $(1983 / 2011,125)$ so that they are not larger than 500,000 individuals. It is unlikely that many families who have lived for a long time in communities within large cities would volunteer to move away. In the 1970s, the compulsory depopulation of cities based on the idealisation of rural life in villages and the ideology of the creation of an agrarian socialism resulted in genocide under Pol-Pot's Khmer Rouge in Cambodia. This should teach us a historical lesson about attempts to ruralise society.

In bolo'bolo, decisions on all of the organisational levels of a communist society are made based on a system of "delegation from below" (122), where two delegates are chosen by lots to represent a unit in an assembly for a limited period of time, where a small number of external delegates and delegates from neighbouring units are also represented. There are bolo assemblies, township assemblies, county assemblies, regional assemblies, and one planetary assembly.

The assembly meetings are transparent and broadcast on television (123). P.M. seems to see such assemblies as a kind of government that takes decisions. This is certainly one possibility. Another possibility is that there is deliberation within local communities before decisions are made and local constituencies vote on certain options that are suggested in a grassroots manner. In the age of the Internet, individual online debate can support face-to-face meetings and electronic forms of citizen participation in debates are possible.

\subsection{Technology and Production in Communism}

The "real motivation" for individuals to "live together" in a bolo "is a common cultural background" (1983/2011, 84). More complicated forms of production such as construction, water and electricity supply, sewage, the production of machines, tools, clothes, furniture, electronics, etc. depend "on the cultural identity of a given bolo" (96). One problem of the organisational form of the bolo is that it is predominantly a cultural unit of togetherness, where humans come together relatively arbitrarily and spontaneously and not around a shared interest in a particular type of skill or production.

A bolo is predominantly a unit of culture and not of economic production. As a consequence, in such a society there could easily be a large number of bolos that do not have the necessary number of individuals with the skills needed for producing the goods and services necessary for survival. The fact that P.M. suggests that there is no education system in bolo'bolo may easily make skills shortages and educational deficits a severe problem that hampers the survival capacity of bolos and the bolo'bolosociety. If in contrast the basic organisational unit is not a local neighbourhood, but the self-managed company (the co-operative) in a decentralised planned economy, then the anarchy of production can more easily be avoided. P.M.'s vision of bolo'bolo lacks decentralised planning of the economy and could easily end up being a society of general poverty and shortage.

bolo'bolo's anarchy of production should, according to P.M., be overcome by gifts, township-depots of surpluses, exchange, barter agreements, and markets. There are markets as "agreements on importation/exportation of energy" (100). In bolo'bolo, gifting is spontaneous (132), there are common pools of reserves that are given to those communities that require them (133), barter agreements between bolos and at other organisational levels (134-137), and also money-based markets (137-139). In the bolo'bolo-society, there is exchange-value such as "100 bottles local wine" = "20 pounds feta cheese" (136). 
P.M. argues that the need for "economic - i.e., value-calculating - exchange" (137) would be drastically reduced. The problem is that every exchange needs to be based on some standard of exchange and that labour-time is a likely candidate for such a standard. Because of different local production conditions, some organisational units are inevitably more productive than others. In an exchange-economy, the more productive units can attain advantages in barter agreements and as a result accumulate surpluses of certain goods that others cannot obtain. Exchange is always unequal exchange that results in class divisions between richer and poorer individuals, groups, classes, and regions. Marx stresses that when there are different societal and natural conditions of production, "the same quantity of labour satisfies a different mass of requirements in different countries, and consequently under otherwise analogous circumstances, the quantity of necessary labour-time is different" $(1867,650)$. In an exchange-oriented system, units, communities, countries and regions that have a lower productivity face disadvantages and get less in exchange for their products than others. Uneven geographical and social development is a consequence of exchange. A communist society needs to abolish exchange and organise the economy as a hightech, post-scarcity gift economy.

Theodor W. Adorno stresses the dominative and destructive character of all exchange. He argues that barter and exchange mean "an exchange of things that are equal and yet unequal" (1973/2004, 147). In "the institution of exchange there is created and reproduced that antagonism which could at any time bring organized society to ultimate catastrophe and destroy it" (Adorno 1969/1970, 149). Emancipation requires the ability to "transcend barter" (1973/2004, 147). In "post-capitalist societies", "there can be no question that exchange will have ceased to take place" $(2000,31)$.

P.M. writes that computer networks could be used in bolo'bolo for storing offers for barter agreements that "could be consulted by others who're looking for a certain product” (1983/2011, 135). In high-tech, post-scarcity, digital communism, exchange becomes superfluous and production and distribution can, with the help of global computer networks, be organised as a needs-based economy. Households and local communities can enter their local demand for certain products and services for particular periods of time (such as one month) into a global economic database that is accessible to everyone and therefore also to the producers of these goods who can orient their production activities towards actual needs.

Self-managed companies specialising in certain forms of production know what their average productivity is and can thereby calculate how many products they are able and willing to produce per month. They also enter their average output per unit of time into a global database. If such computer-based needs assessment and computerbased production planning is organised globally, then an Internet-based process of decentralised economic planning is realised. An algorithm calculates what share of the products created in a particular self-managed company is allocated to what local community. In order to avoid high levels of transportation, the principle is used that goods that satisfy the needs of individuals in certain local communities are produced in the geographically closest companies that have a corresponding production capacity. Inevitably, there will be shortages of certain important products in particular regions, such that physical transportation of goods will not cease to exist, but become part of a global solidary gift economy without exchange. A computerised, networked post-scarcity socialist society does not need any form of exchange. The computerised decentralised planning process identifies global shortages, which allows the planning of mitigation strategies. 
Although P.M. says that in a future society there should be no limits on "pleasure and adventure" (55) he argues for the organisation of bolos, towns and regions as a "relatively lame, harmless, low-productivity affair" (119), which implies low productivity and the existence of toil. It is therefore no surprise that bolo'bolo does not discuss automation and robots. A communist society is a society where there is wealth for all, which requires high technology, high productivity and the abolition or at least massive reduction of toil. The communist shaping and use of computing and robots can automate alienated labour. Full automation is neither possible nor desirable because there are many creative activities that humans want to conduct, complex activities where robotic decisions are dangerous or impossible, and social activities where robotic activities are inhumane (e.g. the education of children or the emotional and social care of the sick and elderly).

But there are also activities that are objectively alienated, such as waste collection or the cleaning of toilets, sewage systems and sewage plants. Socialising the labour of cleaners of public toilets and sewage divers so that everyone has to do such dirty work for some hours per week does not make it less alienated. A communist society cannot exist without the cleaning of public toilets, the collection and recycling of garbage, and the maintenance of sewage drains and sewage plants. The solution is, however, not that we learn to love dirt and shit and stop the work of cleaning, as P.M. suggests ("Dirt and the right to be dirty can even be a form of luxury", 103), but that such labour is automated and in a communist society conducted by toilet- and sewagedrain-cleaning robots and waste-collecting and waste-recycling robots. A communist society without toilet- and sewage drain-cleaning robots is unimaginable. Technical progress has been made in the development of toilet-cleaning robots. Giddel is the world's first portable toilet-cleaning robot. Such robots should be widely used for cleaning public toilets in a communist society and should also be available for households, where individuals, families, or collectives of individuals live who want to use cleaning robots.

\subsection{Communication and Culture in Communism}

In bolo'bolo, there are no specialised institutions, including educational institutions such as schools and universities $(1983 / 2011,112)$. There is also no compulsory literacy (113). Knowledge is "acquired on the job" (113). There are cultural centres, and increased amounts of free time are used for cultural activities (114). The university "will become universal", there will be "more possibilities for information and research"; "science will be in the reach of everyone" (114).

It is difficult to see how skills and knowledge could diversify and become universal without schools and universities. Reading, writing, mathematics, abstract and critical thinking are not simply acquired as part of training on the job, but require in-depth engagement with knowledge in social learning communities. There is a danger that bolo'bolo is a highly pragmatic society that is oriented on instrumental skills and does not nurture mass intellectuality, critical and creative thinking, and the complex skills and technologies emanating from such thought. As a consequence, bolo'bolo could mean a return to the agricultural age, featuring toil, poverty, scarcity, hard labour, and low living standards. A communist society must be a technologically highly productive information society or it will not exist.

That schools and universities continue to exist in a communist society does not mean that these institutions will take the same form as today. They will have a more democratic and participatory character and be oriented on the principle that we can all 
best learn from others and in communities of learners without learning pressure and a grading system.

"Communication in itself will have a different character under the conditions of bolo'bolo" (114). According to P.M., in bolo'bolo there is a much higher level of interpersonal communication for spreading news, so that there is no mass press: "Paper information will be limited to bulletins of all kinds, to proceedings of neighbourhood or city assemblies [...] and to reviews" (115). P.M. seems to assume that most global and trans-local communication organised by the media system stems from the antagonisms of capitalism and the state. There is a danger that the elimination of regional, international and global media and communication systems would support localised forms of bigotry and nationalism. A truly communist society consists of individuals who are curious about individuals, communities and life in other parts of the world. Newspapers, television, radio and Internet communication would lose their capitalist character as means of advertising, sale, ideology, and become global means of information, communication, news, entertainment, debate, participation, and collaboration. Truly participatory media can only exist in a communist society, in which the common ownership of the means of production exists and these means are used for common production (citizen journalism), common debate, and the common participation of everyday individuals. Communism does not have to abolish, but to radically transform the contemporary means of communication.

bolo'bolo was written at a time when computer networks such as the ARPANET and Minitel existed, but had not yet reached the status and reach that e-mail, the Internet, and the World Wide Web have today as international and global means of communication. P.M.'s suggestions for how to use the means of communication focus on local applications with low-usage capacities:

Local cable-TV networks, radio stations, video libraries, etc., can be installed by local organisms (see tega, vudo) and remain under the control of the collective users" (116).

Already at this moment there's a computer terminal for every bolo on the planet - no more production is necessary. The telephone network could also be completed in such a way that every bolo could have at least one station. This means that it could be connected with regional or planetary processors or data-banks. Of course, every bolo would have to decide on the basis of its cultural background whether it needs such means of communication or not" (117).

In the early 1980s P.M. probably did not have the utopian vision of imagining the existence of the global communication system of the Internet and how it could be repurposed in a communist society as means for global cultural production and global economic and administrative co-ordination, but there is also a certain degree of fetishism of localism and local communities in his approach. Communist societies have to be 'glocal', i.e. based on a dialectic of the global and the local that combines global localities and local globality as unity within diversity, in order to avoid both localist bigotry (diversity without unity) and globalist cultural domination (unity without diversity).

P.M.'s claim that "bolo'bolo will not be an electronic civilization - computers are typical for centralized, depersonalized systems" (116) blames the computer as such for the ills of bureaucracy and class society. Communism will be, among many things, a form of digital, post-industrial socialism or it will not exist.

In his later work Kartoffeln und Computer (Potatoes and Computers), P.M. stresses that commons are resources that are necessary for all humans and are maintained by 
a community. As a consequence, commons should not be private property or a commodity, but be accessible to all and collectively controlled. Land (food, resources, energy, etc.) and knowledge ("the capacity to use and improve all means of production") are two key types of the commons (P.M. 2009, 17). The commons are "all about potatoes and computers" $(2009,17)$. In his later works, P.M. gives much more attention than in earlier works to the role of computing in communism. He argues that "co-operatories' are spaces where knowledge is shared and becomes a common. The Internet "can function as a global on-line cooperatory", but computer-supported co-operation would have to be a combination of "internet and face-to-face gatherings" $(2009,19)$. The Internet could also play a key role in the organisation of the economy:

A postcapitalist household system is in principle demand-oriented. Instead of dumping commodities onto a market, goods that are needed are ordered by the consumers (who in turn are organised democratically on various levels). The producers (the same people wearing different hats) try to match these orders with the available resources (including their capacity or willingness to produce them) and give feedback to the ordering persons/institutions, who in turn modify their orders. This system of iterative planning seems clumsy, but computer programmes that can support it already exist. According to Paul Cockshott and Allin Cottrell's Towards a New Socialism, there is no amount of complexity that such planning algorithms couldn't handle" $(2009,22)$.

Cockshott and Cottrell $(1993,118)$ propose the creation of "a socialist market in consumer goods" that uses computerised planning so that prices are regulated according to labour-values. In their suggested system, labour-values of goods are calculated by recording labour-times as well as the inputs and outputs for the production in each company and for each commodity.

In our hypothetical socialist economy, each unit of production would use such a package to build a model of their production process. The spreadsheet model would have fed into it how much labour had been used over the last week, how much of each other input, and what the gross output had been. Given up-todate figures for the labour values of the various inputs, the spreadsheet would rapidly compute the labour values of the outputs. [...] The whole system would be acting as a huge distributed supercomputer continuously evaluating labour values by the method of successive approximation (Cockshott and Cottrell 1993, 59).

Based on an algorithm, the commodity prices and target outputs of companies are set accordingly.

In Cockshott and Cottrell's version of socialism, commodities, prices, markets, exchange-value, and wage-labour (although not remunerated in money, but in labour credits, which is another general medium of exchange) continue to exist. The two authors underestimate how high levels of productivity and networked communication enable the elimination of exchange-value and the creation of a gift economy. Nick DyerWitheford $(2013,14)$ argues that automation as well as the copying of digital content and hardware (3D printing) and peer-to-peer production, enabling decommodification and the creation of digital commons, point in the direction of a communist system, where 
scarcity is replaced with plentitude, ending the need for either prices or planning. For Marxists, 'plenty' yields the transition from the 'lower' phase of communism, which still must grapple with problems of scarcity, to the higher phase of 'from each according to his abilities, to each according to his needs"' $(2013,14)$.

Evgeny Morozov $(2019,54)$ suggests the use of the feedback infrastructure enabled by digital technologies and big data for "non-market forms of social coordination", such as bringing together "problem-finders" and "problem-solvers" in collaborative digital problem-solving $(2019,56)$, the design of non-markets $(57)$, or decentralised planning of the economy (62-65): "On the consumption side, the predictive capacity of Big Data can anticipate our preferences better than we can; [...] Likewise on the production side, 3D printers enable cheap and flexible manufacturing, without the need for massive fixed-capital investment" $(62,63)$.

Morozov refers to Daniel Saros' (2014) approach for suggesting the creation of a digital socialist market economy:

At the centre of his system stands a General Catalogue, something of a mix between Amazon and Google, where producers, who are organized in guild-like 'worker councils' - worker-run startups if you will - list their products and services in a way that would be familiar to users of Apple's App Store or Google's Play Store. Consumers, equipped with a unique digital id card, turn to the catalogue to register their needs during the so-called 'needs registration period' at the beginning of each production cycle; they rank the products they want, specifying their quantities for the next cycle. Consumers can still purchase products they didn't request after the need-registration period ends, but they receive higher bonuses if their purchases do not deviate from their initial predictions" (Morozov 2019, 64).

In the economic system both Saros and Morozov suggest, companies do not make profit, but commodities, exchange-value, money, and markets still exist; this also implies the existence of wage-labour. Production is more needs-oriented because consumers indicate their needs in a decentralised manner over a networked database system.

But given that exchange is always unequal exchange, there will be unequal distribution of money and goods and unequal purchasing power in such a system. In addition, some co-operatives will sell more and be more productive than others, which may result in bankruptcy, overproduction, crises, precarious working conditions, wage cuts, lay-offs of certain groups of workers, unemployment, etc. Exchange-value, commodities, wages, and markets are unnecessary mediators of the economy which create inequalities. 21st-century socialism requires a decentralised system of planning that uses a networked information system that is organised over the Internet.

In such a decentralised communist information system, humans register their needs and wants, co-operatives' production capacities are recorded, and both sets of data are co-ordinated so that co-operatives produce use-values that correspond to actual needs and wants. Data-based recommendation systems that use a publicly transparent open access algorithm for assessing the defined needs of consumers and suggesting what other goods the consumer might be interested in can be organised via the networked planning system. For such a system, no money, no commodities, no exchange, no markets, and no wage-labour are needed. Socialism must aim at eliminating these forms of economic mediation right from the start and in their place implement a socialist gift economy. As far as possible, a socialist economy should also make 
use of the automatic and robot-supported production, distribution, repair, disposal, and recycling of goods.

In Kartoffeln und Computer, P.M. puts more stress on gifts and commons and less on markets and exchange than in bolo'bolo. He argues that markets are "terribly wasteful" $(2009,22)$ but nonetheless suggests that creative enterprises "may operate with market systems, with money, bartering, gifts or just when there is occasional demand" (19), which contradicts his argument in the same book that knowledge should be treated as a common good available to everyone. Once a market and exchange are introduced, there are mechanisms that exclude humans from wealth.

\subsection{The Communist Allocation Algorithm}

The allocation of the amounts of products that consumers need from the producers is the key economic issue in a communist economy. Networked computing can be used for supporting the organisation of economic allocation. For the allocation process itself, the consumers and producers need to deal with the following questions:

- Q1: How many goods of the types $g_{1}, g_{2}, \ldots g_{i}$ does consumer $c_{j}$ want and need in a certain period of time?

- Q2: What producing unit (co-operative) pi produces how many units of a certain good during a particular period of time (e.g. one month)?

- Q3: How many hours during a certain period of time does individual $i_{i}$ make available in order to produce a certain good $g_{j}$ according to their abilities and in what co-operative $\mathrm{pk}_{\mathrm{k}}$ do they work?

- Q4: What is co-operative pi's productivity, i.e. how many goods of a certain type $\mathrm{g}_{\mathrm{j}}$ does it produce during a particular period of time?

- Q5: In co-operative $\mathrm{p}_{\mathrm{i}}$, what amount of goods-type $\mathrm{g}_{\mathrm{j}}$ are produced by robots and what amount by humans during a certain period of time?

- Q6: Allocation function: What amounts of goods $g_{1}, g_{2}, \ldots g_{i}$ do co-ops $p_{1}, p_{2}, \ldots p_{j}$ produce and what amounts of these goods are delivered to consumers/communities $\mathrm{C}_{1}, \mathrm{C}_{2}, \ldots \mathrm{C}_{\mathrm{k}}$ ?

- Q7: Given certain needs and productivity levels, can a sufficient amount of the goods $g_{1}, g_{2}, \ldots$ gi be produced during a certain period of time? If there are goods where the need is going to be larger than the expected production capacity, what mitigating measures can be taken?

- Q8: What amount of reserves of the goods $g_{1}, g_{2}, \ldots g_{i}$ should be produced by what co-operatives in order to mitigate against economic crises?

A key aspect of the communist gift economy is the allocation of co-operatives' production capacity to the quantities of goods needed and requested by consumers and communities so that production is organised in such a way that transport distances are kept at a minimum. Physical proximity is important in order to reduce transport time, transport labour, and possible negative effects of transport on the environment.

Using software and networked computing, an allocation algorithm is used for defining what producer produces what amount of a certain good for whom. This algorithm is run in order to create an allocation matrix at the start of a production period (e.g. at the start of each month). Networked computing as infrastructure that runs the allocation algorithm is used for communicating to producers what amounts they produce and for whom. Here is the syntax of such an algorithm: 
Goods types: $G[1,2, \ldots M]$, there are $M$ types of goods that are needed, $G[1]$ is the ID of goods type number 1

Consumers: $C[1,2, \ldots N]$, there are $N$ consumers, consumers can be individuals, households or organisations or communities, C[1] is the ID of consumer number 1

Producers: $P[1,2, \ldots \mathrm{O}]$, there are $\mathrm{O}$ producers; producers are individuals, co-operatives or other organisations, $\mathrm{P}[1]$ is the ID of producer number 1

Variable matrixes that are defined per period of time (e.g. one month) by producers and consumers respectively:

Consumers: Needs matrix NEED $[\mathrm{x}, \mathrm{y}]$ : the amount that consumer $\mathrm{C}[\mathrm{x}]$ requires of good $\mathrm{G}[\mathrm{y}]$ during the production period (e.g. during one month)

Producers: Production capacity matrix PCAPC $[x, y]$ : the amount of good $G[y]$ that producer $\mathrm{P}[\mathrm{x}]$ can produce during the production period

\section{Available functions:}

$x=\operatorname{CLOSEST}(y, z, \operatorname{NEED}[y, z])$

This function provides the ID of the producer $\mathrm{P}[\mathrm{x}]$ that is in closest physical proximity to consumer $\mathrm{C}[\mathrm{y}]$ and is capable of producing the amount the consumer needs of good $\mathrm{G}[\mathrm{z}]$. If the producer's capacity is already fully allocated, then the next closest producer's capacity is checked. The function returns the ID of the producer that is located closest to the consumer and can produce the latter's demand of a certain good. If no producer is available, then the function returns the value 0 . The function CLOSEST uses the production capacity matrix PCAPC $[\mathrm{i}, \mathrm{z}], \mathrm{i}=1 \ldots \mathrm{O}$, the needs matrix NEED $[\mathrm{y}, \mathrm{z}]$, and a database and a function that together provide the distances between consumers and producers in order to determine the right producer and store its ID in variable $\mathrm{x}$.

Allocation matrix:

For a particular production period, the allocation algorithm defines a three-dimensional allocation matrix $A[x, y, z]$ that specifies the amount of good $G[z]$ that producer $P[x]$ producers for consumption by consumer $\mathrm{C}[\mathrm{y}]$

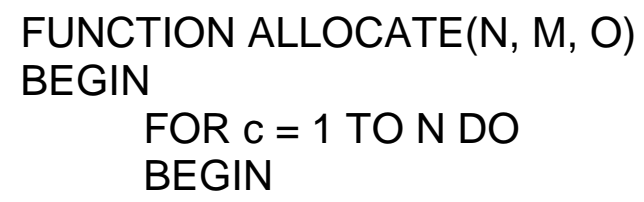

END.

END. 
The ALLOCATE-algorithm defines the allocation matrix $A[x, y, z]$. If there is no production capacity available for fulfilling the need of a certain consumer, then the specific cells in the three-dimensional matrix contain the symbol " $\mathrm{N}$ " (no capacity). For example, if consumer $C(123)$ requires two goods $G(999)$ for which there is no production capacity, then the algorithm fills all matrix cells $A[i, 123,999], i=1,2, \ldots O$ (all producers) are filled with the symbol "N". After the allocation algorithm has been run, one knows if and what production shortages exist.

If there are significant shortages then there is a need to mitigate. One mitigation strategy is that each producer always tries to produce a reserve of e.g. 10 percent of each good that are used when shortages occur. A second option is that one tries to use additional robots to create more products. A third option is that calls are sent out over the producer/consumer-Internet app communicating that a certain amount of working hours is needed in order to satisfy society's need and that volunteers are sought who work for a certain amount of hours in a particular co-operative. If there are not enough volunteers or not enough robots available, then a maximum amount of goods that consumers can receive of the scare good can be introduced for a limited period of time.

\subsection{Conclusion}

bolo'bolo is a book that inspires the reader to think about how a communist society could look and what organisational features are needed to overcome class, capitalism, the state, nations, borders, exploitation, and domination. P.M.'s vision is a commune of local communes that is based on grassroots democracy, self-managed production, and autonomous life organised without capital, class, and the state. He envisions a participatory society that has a grassroots character.

There are limits of P.M,'s vision in respect to the use of communication technologies, computers, and robots, where the book is not visionary and not utopian enough and is in danger of idealising local, rural life that is based on hard physical labour and has low levels of productivity.

P.M.'s bolo'bolo and Kartoffeln und Computer are important contributions to discussions about post-capitalism and show that alternatives to capitalism are feasible. How such alternatives should best be organised is debatable and is a practical and collective question of the realisation of concrete utopias.

\section{Other Novels About Post-Scarcity Communism}

Charlotte Perkins Gilman's (1911/2018) novel Moving the Mountain plays in a future post-scarcity society, where eugenics is practiced in order to kill the mentally ill, the disabled and criminals. Published in 1911, the novel cannot envision a society where computing plays an important role.

In Philip José Farmer's (1967/1992) Riders of the Purple Wage, there is a postscarcity society where everyone receives a basic income and people live in segregated communities, there is government surveillance and a sterilisation programme, and citizens engage in anti-social behaviour, including sex between children and parents, forced emigration, and riots and violence in the arts scene.

Samuel Delany's (1976/1996) Trouble on Triton is a direct response to Le Guin's The Dispossessed. Delany focuses on Bron Helstrom, a troubled and unhappy character living in the utopian society Triton, which is at war with Earth. Triton is a socialist society where computers play a role. But the novel is too preoccupied with subjectivity to deal with questions such as how production and distribution work, how garbage is collected, or what role computers play in the economy. 
In Kim Stanley Robinson's (1992; 1993; 1996) Mars Trilogy, a post-scarcity society is established on Mars. The plot focuses on the settlement of Mars, where longevity becomes possible, and conflicts over emigration from an Earth ridden by wars, environmental disasters and transnational corporations' dictatorship. The book predominantly focuses on conflicts and wars that shape the build-up of a communist society on Mars and is not so much focused on communism itself.

In James P. Hogan's (1992) Voyage from Yesteryear, a space expedition escapes from global war and authoritarianism on Earth and establishes a communist post-scarcity society on Chiron, a planet in the Alpha Centauri star system. The economy is automated and human labour has been replaced by robot activities. The plot focuses on how the rulers of Earth try to conquer Chiron and implement fascist rule on the planet.

In Down and Out in the Magic Kingdom (2003) Cory Doctorow presents stories that are set in the Bitchun society, which features immortality, post-scarcity, and the respect of fundamental rights. There is a digitally-organised reputation system called Whuffie that measures how popular an individual is and provides privileges to the most liked individuals. The plot revolves around a turf war between two rival adhocracies about the control of Disney World. Doctorow's (2017) Walkaway describes a dystopian postscarcity society where the rich elite rules over citizens in a dictatorial manner, citizens are under constant surveillance, and military force is used against rebels who walk away from this repressive society.

lain M. Banks' (2011) Culture series consists of nine novels and a volume of short stories. The Culture is an anarcho-communist society where the economy is automated, there is no state, and Artificial Intelligence systems ("the Minds") conduct all administration. The plot focuses on wars and conflicts with less-developed societies on other planets, such as the Idiran War between the Culture and the militaristic Idirans, and how the Culture uses espionage, agents, and special operations for defending its society and expanding its influence. The novels are more focused on interstellar conflicts than on how a highly automated communist economy and a communist society work.

Ken MacLeod's stories, novels, and book series, such as the Fall Revolution Series (2008; 2009), the Engines of Light Trilogy (2000; 2001; 2002), and The Corporation Wars (2018), are often science fiction space operas that involve life on other planets and focus on wars and conflicts between communists and their enemies.

Most of the mentioned novels are either dystopian, or contain no computing, or do not focus much on how the economy works. They are preoccupied with wars, espionage, and conflicts that are all too characteristic of contemporary capitalist society. A genre of post-scarcity communist novels, where technologies are used in a humane way and society is democratic and participatory and the plot revolves around the organisation of the economy and society, has yet to be created.

\section{Conclusions}

There are important lessons we can learn for the organisation of a future communist society from the readings of communist utopias presented in this paper.

\subsection{William Morris's News from Nowhere:}

\section{Beauty as a principle of society:}

What we can learn from Morris's utopian communist society is the importance of the principle of abundant beauty and the advancement of possibilities for creative work 
and work as art and play. Morris underestimates the potentials for modern technologies and could not envision a post-industrial socialism where computing technologies and knowledge work play an important role and enable the end of toil, unpleasant and dangerous labour and the maximisation of free, self-determined time used for leisure, creativity, social engagement, political debate, art, and human togetherness.

\section{Machines for the conduct of dangerous, unpleasant, stupefying, monotonous, and physical labour:}

A highly productive post-industrial socialism where robots and computing are used for providing possibilities to automate dangerous, unpleasant, stupefying, monotonous, and physical labour is less likely to turn back into a class society and more likely to provide happiness for all. Morris overestimated the interest and capacity of humans to find pleasure in mundane, hard physical labour. In a highly productive digital-communist society, humans can volunteer to conduct hard labour if they indeed find it pleasurable, but a decisive feature of such a society is that there are machines available that can to a significant degree conduct such work or make it less alienating.

\section{The beauty of interpersonal relations and communication:}

We can learn from News from Nowhere that communism is likely to transform human culture, manners and behaviour so that humans are less aggressive and engage with each other in much more friendly, open-minded, caring, and solidary manners than today. Beauty will not just be a feature of the natural and physical world, but also be a characteristic of the human character and interpersonal relations.

\section{Participatory democracy as communist politics:}

The political system of a communist society requires the participation of humans in making decisions that concern their lives. Participatory democracy is the political system of a communist society. In such a society, there is enough motivation, interest and time available for humans to engage in political debates and decision-making. Computer networks will support democratic information and communication; not replacing, but rather enhancing face-to-face assemblies and debates.

\section{Communist transport and communication:}

In a communist society, transport and communication should not mean toil and localism, unlike in News from Nowhere, but, based on green computing and green transport, technologies should enable humans to communicate and travel globally so that they learn from each other, enjoy discovering the world and meeting other people in distant cultures, and create a global community of friends. In a communist society, schools would continue to exist, but be organised as participatory organisations. Learning, reading, writing, art, critical thinking, critical arguing, critical reading, critical writing and critical debating would be encouraged and practiced in cultural communities of life-long learners and cultural creators. Digital technologies would be used for supporting these critical and cultural skills. Certainly, there would be less need for global transport in a communist society than in capitalism because commodities and exploitation will have disappeared. Fossil-fuel driven, individually-owned cars are unlikely to exist, but there would be effective networks of public transport. Fewer long-distance flights and travels than today would be needed. Rockets, aeroplanes, buses, railways, trams, ships, cars, lorries, mopeds, cable cars, etc. would be solar-driven or powered 
by other forms of green energy. Those who enjoy driving buses or piloting ships or aeroplanes would be able to do so. But there will also be the possibility to use highly developed, secure self-driving vehicles that make use of Artificial Intelligence.

\subsection{Peter Kropotkin's The Conquest for Bread:}

\section{Wealth and luxury for all in the digital age:}

Kropotkin's communism is based on the collective ownership of the means of production that enables wealth for all and luxury for all. In 21 st-century society, wealth for all also includes the access of all to the world's knowledge as knowledge and digital commons and the gratis access of all to creative and digital skills and the cultural resources needed for universal artistic and creative production so that everyone can become an artistically and an intellectually accomplished.

\section{Post-scarcity digital communism:}

For Kropotkin, communism is a highly productive, post-scarcity society that makes use of and further develops the means of production. In the 21st century, communism can make use of digital technologies in order to increase productivity and create wealth and luxury for all beyond scarcity and necessity. Kropotkin recalls that communism requires technological foundations and that communism today requires digital foundations. Future communism in the $21 \mathrm{st}$ and 22 nd centuries requires digital machines in order to automate as widely as possible dangerous, exhausting, monotonous, mundane, boring, and unpleasant necessary labour.

\section{Communist agro-industrial-digital communes:}

Kropotkin argues for the creation of agro-industrial communes. In a digital communist society, we need communist agro-industrial-digital communes, where digital technologies advance the digital support of agriculture, manufacturing and services so that the division of labour can be abolished, necessary labour can be minimised, and free work beyond necessity and compulsion can be maximised. Given that the computer is a universal machine, it can in a communist society be used as a tool that supports the sublation of the division of labour so that everyone can become an intellectual, an artist, and both a manual and a mental worker. Digital communism will create wellrounded individuals using digital technologies.

\subsection{Ursula K. Le Guin's The Dispossessed:}

\section{The need for post-scarcity communism:}

The Dispossessed's ambivalent utopia shows that whereas capitalism fetishizes individualism without nourishing the collective and common good, the socialism of scarcity fetishizes collectivism without individuality and does not give enough space to individual interests and needs. High productivity is a necessary, but not sufficient condition for a socialism with wealth and happiness for all.

\section{The communist social character:}

The book's main protagonist Shevek is a communist who wants to support the creation of common goods that foster universal friendship, mutual aid, and universal solidarity. 
Shevek creates his theory of time because it can underpin the creation of an instantaneous, interstellar communication system, an Internet of the Universe that is called the ansible, which is short for "the answerable". Like Tim Berners-Lee, who made the World Wide Web a commons, Shevek does not want to earn money from his theory and the resulting communication system, but wants to give his ideas to the world as a gift. For Shevek, communication is an important foundation of peace in the Universe.

\section{The Internet of the Universe as interstellar public sphere:}

For Shevek, communication is an important foundation of universal peace. He imagines the creation of an interstellar public sphere that fosters peace and understanding. We can learn from Le Guin's works that universal and global communication systems need to rid themselves of commodification and authoritarianism and be designed and used in a participatory-democratic manner in order to foster the public sphere, peace and global understanding. A communist society needs a communist system of communication that is based on the principle of common access, common use, and the creation of possibilities for common encounters of humans that strengthen solidary and friendship.

\subsection{P.M.'s bolo'bolo and Kartoffeln und Computer}

\section{The communist gift economy:}

We can learn from P.M.'s works that contemporary societies are productive enough and provide powerful means of networked communication so that decentralised economic planning of production and distribution allows the abolishment of all exchange and the replacement of the commodity economy by the gift economy. Exchange is always unequal exchange that results in class divisions between richer and poorer individuals, groups, classes, and regions. A communist society needs to abolish exchange and organise the economy as a high-tech, post-scarcity gift economy.

\section{Decentralised, computerised planning in the communist economy:}

In high-tech, post-scarcity, digital communism, exchange becomes superfluous and production and distribution can, with the help of global computer networks, be organised as a needs-based economy. Households and local communities can enter their local demand for certain products and services for particular periods of time (such as one month) into a global economic database that is accessible for everyone and therefore also for producers of these goods. Self-managed companies specialising in certain forms of production know what their average productivity is and can thereby calculate how many products they are able and willing to produce per month. They enter their average output per unit of time into a global database. If such computer-based needs assessment and computer-based production planning is organised globally, then an Internet-based process of decentralised economic planning is realised. An algorithm calculates what share of products of a self-managed company is allocated to what local community. In order to avoid high levels of transportation, the principle is used that needs should, as a preference, be satisfied by goods produced in the geographically closest companies. Inevitably, there will be shortages of certain important products in particular regions, so that physical transportation of goods will not cease to exist, but become part of a global solidary gift economy without exchange. 


\section{The automation of unpleasant and dangerous labour in communism:}

Public toilets are highly prone to becoming dirty and dysfunctional. The public toilet is a symbol for the question of how the economy is organised in a communist society. If such a society manages to organise the most unpleasant labour such as the cleaning of public toilets and sewage drains and the collection of garbage, then the communist economy will work. If public toilets overflow and are dysfunctional, then it is also likely that collective housing projects, self-managed companies and society as a whole will be dysfunctional. The question of how public toilets are organised and maintained is a key metaphorical question for communist societies. A communist society cannot exist without the cleaning of public toilets, the collection and recycling of garbage, and the maintenance of sewage drains and sewage plants. The solution is, however, not that we learn to love dirt and shit and stop the work of cleaning, but that such labour is automated and, in a communist society, conducted by toilet-, and sewage drain-cleaning robots and waste-collecting and -recycling robots. A communist society without toilet- and sewage drain-cleaning robots is unimaginable.

\subsection{Guidelines for Writing and Struggles for Utopias of Digital and Communicative Socialism}

From the readings of the discussed communist utopias, we can formulate some guidelines for how storytelling and fiction can best outline concrete utopias of digital and communicative socialism:

\section{Communist digital machines:}

Communism is a highly productive digital society where toil, dangerous, unpleasant and necessary labour have been abolished by alternative scientific and technological progress. Digital machines are used for creating an economy that fulfils human wants and needs. The effects of these machines on society are socially and environmentally sustainable and the development of machines, science and technology is a participatory process where all those who are affected by science and technology's use together take collective decisions.

\section{Wealth and luxury for all in digital communism:}

Digital communism is a society that features wealth and luxury for all in a socially and environmentally sustainable manner. The means of production are common goods owned collectively by those who work with them. Human wealth is a common, which means that the riches that satisfy human needs and wants are available to everyone as gifts without payment. Common goods include the knowledge commons and the digital commons. The means of communication, including digital technologies, are common goods managed in a democratic manner.

\section{Work as art that creates beauty:}

In communism, human toil has disappeared, but human work continues to exist beyond necessity as free activity that humans use for artistic, creative, social, self-fulfilling, selfdetermined and intellectual work, political debate, human togetherness, etc. Work becomes art and humans strive to create a beautiful world that benefits all. Lots of work is conducted in co-operatives as social production. 


\section{The communist social character:}

In concrete-utopian digital communist stories, the reader meets individuals who are representatives of the communist social character. There is beauty in their interpersonal relations and communication. They are friendly, open-minded, caring, and solidary humans who treat others in a humane manner and strive to foster common wealth and common benefits for all.

In stories where we hear about revolutionary situations that aim at overcoming class society or have established a communist society, the communist social character who strives for a society that benefits all plays a particularly important role.

\section{Well-rounded individuality:}

In digital communism, the division of labour and society's divisions have been abolished. There are agro-industrial-digital communes, where digital technologies advance the digital support of agriculture, manufacturing and services. In such a society, it is common that humans do not have a single realm of activity, but undertake multiple creative and social work activities. Humans are well-rounded individuals. Digital technologies support their creativity and well-rounded activities. In communist society, humans are general intellectuals and artists with manifold cultural interests.

\section{The communist economy and decentralised, computerised planning:}

The economy of digital communism is a gift economy without exchange, markets, commodities, money, and wage-labour. It is based on the principle 'from each according to their abilities, to each according to their needs'. Globally networked computing systems are used for organising a needs-based gift economy, where needs and wants are recorded in a decentralised manner, which means that humans and households regularly enter their basic and special needs into a database. The production process is transparent and needs-oriented. The produced amounts of goods are digitally recorded so that the level of productivity of each unit is known. Consumers' wants and needs and production capacities are co-ordinated via decentralised, computerised planning. Production is to a significant degree organised at the local level, but there is also translocal, regional, trans-regional and global gifting organised via computing and environmentally sustainable transport technologies.

\section{Participatory democracy:}

Participatory democracy is communism's political system. Humans have the time, skills, motivation and interest to engage in political assemblies where decisions that concern them are discussed and taken. There are assemblies at various organisational levels of society ranging from the company and local community level to the global level. There are communes, communes of communes, communes of communes of communes, etc. that host assemblies as decision-making bodies. Large assemblies consist of delegates appointed for a limited period of time by their grassroots communities. Networked computer technologies support but do not replace face-to-face meetings.

\section{The digital and global public sphere:}

In digital communism, there is a global public sphere, where humans debate matters of concern vividly and reach understandings. There are no asymmetric power struc- 
tures that colonise the public sphere. The public sphere involves face-to-face encounters as well as the support of political information, communication, collaboration, and co-operation by the global Internet that is free from harassment and bullying and where humans communicate as friends. Digital communism knows no national borders and is not a form of local bigotry and isolationism. It is a glocal society that is based on a dialectic of the local and the global as well as universal and global cultural unity in diversity. Humans encounter each other as friends and fellow human beings. Sustainable communication and transport technologies enable humans to explore the world and make contacts and friends all over the world. The public sphere is to a significant degree a cultural public sphere, where humans encounter each other in order to make new friends and enjoy life together.

\section{Everyday life in digital communism:}

Stories about digital communism provide lots of insights into details of everyday life, including education, family life, friendships, love, birth, food supply, eating, consumption, culture, arts, housing, energy supply, utilities, communication, the means of communication, transportation, entertainment, sports, privacy, health, illness, social care, death, gender relations, sexuality, etc. The stories also outline what positive roles digital technologies play in everyday life and where they do not play a role because their use is considered harmful.

\section{Transformation, revolution, the capitalist past:}

Stories about digital communism also compare the organisation of and everyday life in digital communism to past stages of history, where capitalism or other class societies existed. They also reveal how the revolutionary transition to communism took place. There are comparisons between means of production/communication, including the digital means of communication and digital machines, in class society and in digital communism. The design, use, and impacts of technologies in capitalism and communism are compared.

\section{Contradictions:}

If communist novels, stories and fiction focus predominantly on problems, conflicts, wars, or violence in respect to communism, communist technology, or the relationship of communism and class society, then there is the danger that the impression is created that communism can never work and should not be created in the first instance. A pure focus on such issues should therefore be avoided.

But digital communism is not a society that is free from contradictions and problems. There are problems and contradictions of digital communism that we learn about in concrete-utopian communist stories. But class relations, exploitation, and domination do not exist, which makes it easier to solve problems and deal with contradictions. Digital communism is a problem-solving society, where humans are in general creative, intellectual, critical beings who together engage in trying to solve the problems society is facing. In some stories, digital communism comes under the threat by hostile groups or societies, who threaten to invade and destroy communism and to impose a class rule. Such stories show how digital communism deals with existential threats in a resilient manner. Occasionally, there are stories in which such threats turn digital communism from utopia into dystopia and later back into utopia. 


\section{Dialectical technology:}

Raymond Williams (1978/2005) argues that it is problematic when technological transformations in fiction are presented based on the logic of "technological determinism", where there is "little or no social agency" and technology has "certain 'inevitable' social consequences" $(1978 / 2005,198)$. In such stories, technological transformation is the opposite of humans' wilful transformation; there is no dialectic of society and technology. Utopia and dystopia are "narrowed from agency to instrumentality" (199). Science fiction is scientific, then, because science and technology take on an instrumental character.

In the concrete utopian-communist story it is important that science and technology are presented as dialectical. In both capitalism and communism, there is a dialectic of science/technology and society. The consequences and impacts of science and technology on society are not inevitable, but depend on human interests and on how humans shape science, technology, and society. Utopian and dystopian technological impacts are not natural consequences of science, technology, or society. Science and technology often have multiple, contradictory potentials, realities, impacts, and consequences. In a communist society, science and technology are far from perfect, but also contradictory. It is, however, more likely that they have positive consequences and impacts than in class society. If something goes wrong, then it is easier in such a social formation for humans to intervene, undertake mitigating interventions and undo negative impacts.

Dialectical technology depends on dialectics of technology and society, continuity and discontinuity, agency and structure. In concrete-utopian communist stories, there are struggles for a good society that involve struggles for and about good technology. Utopian-communist literature needs struggling, humanist, solidary communist social characters such as Le Guin's Shevek or the revolutionaries in Morris's chapters on "How the Change Came" (Chapter XVII) and "The Beginning of the New Life" (Chapter XVIII). Such communist social characters should also be present in respect to the dialectics of technology.

\section{References}

Adorno, Theodor W. 2000. Introduction to Sociology. Stanford: Stanford University Press.

Adorno, Theodor W. 1973/2004. Negative Dialectics. London: Routledge.

Adorno, Theodor W. 1969/1970. Society. Salmagundi 10/11: 144-153.

Banks, lain. 2011. Culture Series: 10 Books Collection. London: Orbit.

Bellamy, Edward. 1888/2007. Looking Backward 2000 - 1987. Oxford World Classics. Oxford: Oxford University Press.

Bloch, Ernst. 1995. The Principle of Hope. Three Volumes. Cambridge, MA: The MIT Press.

Bookchin, Murray. 1992. Urbanization Without Cities: The Rise and Decline of Citizenship. Montreal: Black Rose Books.

Bookchin, Murray. 1986. Post-Scarcity Anarchism. Montreal: Black Rose Books.

Cockshott, Paul W. and Allin Cottrell. 1993. Towards A New Socialism. Nottingham: Spokesman.

Delany, Samuel. 1976/1996. Trouble on Triton. Middletown, CT: Wesleyan University Press.

Doctorow, Cory. 2017. Walkaway. New York: Tor.

Doctorow, Cory. 2003. Down and Out in the Magic Kingdom. New York: Tor.

Dyer-Witheford, Nick. 2013. Red Plenty Platforms. Culture Machine 14.

Engels, Friedrich. 1880. Socialism: Utopian and Scientific. In MECW Volume 24, 281-325. London: Lawrence \& Wishart.

Farmer, Philip José. 1967/1992. Riders of the Purple Wage. New York: Tor. 
Frase, Peter. 2016. Four Futures: Life After Capitalism. London: Verso.

Freedman, Carl. 2000. Critical Theory and Science Fiction. Middleton, CT: Wesleyan University Press.

Fromm, Erich. 1960. Foreword to Edward Bellamy's “Looking Backward 2000 - 1987". Accessed January 6, 2020. https://opus4.kobv.de/opus4-Fromm/files/1135/1960f-eng.pdf

Fuchs, Christian. 2019. Nationalism on the Internet: Critical Theory and Ideology in the Age of Social Media and Fake News. New York: Routledge.

Fuchs, Christian. 2018. Digital Demagogue: Authoritarian Capitalism in the Age of Trump and Twitter. London: Pluto Press.

Habermas, Jürgen. 1991. The Structural Transformation of the Public Sphere. An Inquiry into A Category of Bourgeois Society. Cambridge, MA: MIT Press.

Hamner, Everett L. 2005. The Gap in the Wall: Partnership, Physics, and Politics in The Dispossessed. In The New Utopian Politics of Ursual K. Le Guin's "The Dispossessed”, edited by Laurence Davis and Peter Stillman, 219-231. Lanham, MD: Lexington Books.

Hogan, James P. 1992. Voyage from Yesteryear. New York: Del Rey.

Jameson, Frederic. 2005. Archaeologies of the Future. The Desire Called Utopia and Other Science Fictions. London: Verso.

Jameson, Frederic. 1991. Postmodernism, or, The Cultural Logic of Late Capitalism. Durham, NC: Duke University Press.

Kropotkin, Peter. 1892/1995. The Conquest of Bread. In The Conquest of Bread and Other Writings, edited by Marshall S. Shatz, 1-199. Cambridge: Cambridge University Press.

Le Guin, Ursula K. 2004. A Rant About "Technology". https://www.ursulakleguin.com/NoteTechnology.html

Le Guin, Ursula K. 1974/2002. The Dispossessed. London: Gollancz.

Le Guin, Ursula K. 1969/2017. The Left Hand of Darkness. London: Gateway. Kindle edition.

Le Guin, Ursula K. 1966/2015. Rocannon's World. London: Gateway. Kindle edition.

Lukács, Georg. 1962. The Historical Novel. London: Merlin.

MacLeod, Ken. 2018. The Corporation Wars Trilogy. London: Orbit.

MacLeod, Ken. 2009. Divisions. New York: Orb.

MacLeod, Ken. 2008. Fractions. New York: Orb.

MacLeod, Ken. 2002. Engine City. London: Orbit.

MacLeod, Ken. 2001. Dark Light. Orbit. London: Orbit.

MacLeod, Ken. 2000. Cosmonaut Keep. London: Orbit.

Marcuse, Herbert. 1969. An Essay of Liberation. Boston, MA: Beacon Press.

Marcuse, Herbert. 1964. One-Dimensional Man. Studies in the Ideology of Advanced Industrial Society. London: Routledge.

Marx, Karl. 1875. Critique of the Gotha Programme. In MECW Volume 24, 75-99. London: Lawrence \& Wishart.

Marx, Karl. 1867. Capital Volume One. London: Penguin.

Marx, Karl. 1857/1858. Grundrisse. London: Penguin.

Marx, Karl. 1843. Letter from Karl Marx to Arnold Ruge, September 1843. In MECW Volume 3, 141-145. London: Lawrence \& Wishart.

Marx, Karl and Friedrich Engels. 1848. Manifesto of the Communist Party. In MECW Volume 6, 477-519. London: Lawrence \& Wishart.

Marx, Karl and Friedrich Engels. 1845/1846. The German Ideology, MECW Volume 5. London: Lawrence \& Wishart.

Morozov, Evgeny. 2019. Digital Socialism? The Calculation Debate in the Age of Big Data. New Left Review 116/117: 33-67.

Morris, William. 1890/1993. News from Nowhere. In William Morris: "News from Nowhere" and Other Writings, edited by Clive Wilmer, 41-228. London: Penguin. 
Morris, William. 1889. "Looking Backward". Commonweal 180: 194-195. Accessed January 6, 2020. https://www.marxists.org/archive/morris/works/1889/commonweal/06-bellamy.htm

Morris, William. 1884. Useful Work Versus Useless Toil. In The Collected Works of William Morris. Volume 23: Signs of Changes: Lectures on Socialism, 98-120. Cambridge: Cambridge University Press.

Perkins Gilman, Charlotte. 1911/2018. Moving the Mountain. Prague: e-artnow.

P.M. 2012. Kartoffeln und Computer. Märkte durch Gemeinschaften ersetzen. Hamburg: Edition Nautilus.

P.M. 2009. It's All About Potatoes and Computers: Recipes for the Cook-Shops of the Future. Turbulence 5: 17-23.

P.M. 1983/2011. bolo'bolo [30th Anniversary Edition]. Brooklyn: Autonomedia.

Reynolds, Andrew. 2005. Ursula K. Le Guin, Herbert Marcuse, and the Fate of Utopia in the Postmodern. In The New Utopian Politics of Ursual K. Le Guin's "The Dispossessed", edited by Laurence Davis and Peter Stillman, 75-94. Lanham, MD: Lexington Books.

Robinson, Kim Stanley. 2018a. Dystopias Now. Commune 1. Accessed January 6, 2020. https://communemag.com/dystopias-now/

Robinson, Kim Stanley. 2018b. The Realism of Our Time. Radical Philosophy 201: 87-98.

Robinson, Kim Stanley. 2017. Science Fiction is the Realism of Our Time. Talk at the University of Texas at Dallas [video]. 26 April 2019. https://www.youtube.com/watch?v=ApA0 OyVOXE

Robinson, Kim Stanley. 1996. Blue Mars. New York: Bantam.

Robinson, Kim Stanley. 1993. Green Mars. New York: Bantam.

Robinson, Kim Stanley. 1992. Red Mars. New York: Bantam.

Saros, Daniel. 2014. Information Technology and Socialist Construction: The End of Capital and the Transition to Socialism. London: Routledge.

Thompson, Edward P. 2011. William Morris: Romantic to Revolutionary. Oakland: PM Press. USSR. 1936. Constitution of the Union of Soviet Socialist Republics. Accessed January 6, 2020. https://www.marxists.org/reference/archive/stalin/works/1936/12/05.htm

Williams, Raymond. 1978/2005. Utopia and Science Fiction. In Raymond Williams: Culture and Materialism, 196-212. London: Verso.

Williams, Raymond. 1960. Culture and Society 1780 - 1950. Garden City, NY: Anchor Books.

\section{About the Author}

Christian Fuchs

Christian Fuchs is co-editor of tripleC: Communication, Capitalism \& Critique, a critical theorist of society and communication, and author of many books and articles. @fuchschristian; http://fuchs.uti.at 